Biogeosciences, 10, 803-820, 2013

www.biogeosciences.net/10/803/2013/

doi:10.5194/bg-10-803-2013

(C) Author(s) 2013. CC Attribution 3.0 License.

\title{
Late summer particulate organic carbon export and twilight zone remineralisation in the Atlantic sector of the Southern Ocean
}

\author{
F. Planchon ${ }^{1,2,3}$, A.-J. Cavagna ${ }^{4}$, D. Cardinal ${ }^{3,5}$, L. André ${ }^{3}$, and F. Dehairs ${ }^{4}$ \\ ${ }^{1}$ Université Européenne de Bretagne, Brest,France \\ ${ }^{2}$ Laboratoire des Sciences de l'Environnement Marin (LEMAR), Université de Brest, CNRS, IRD, UMR6539, IUEM; \\ Technopôle Brest Iroise, Place Nicolas Copernic, 29280 Plouzané, France \\ ${ }^{3}$ Royal Museum for Central Africa, Geology Department, Tervuren, Belgium \\ ${ }^{4}$ Vrije Universiteit Brussel, Analytical and Environmental Chemistry \& Earth System Sciences, Brussels, Belgium \\ ${ }^{5}$ Laboratoire d'Océanographie et du Climat: Expérimentations et Approches Numériques (LOCEAN), \\ Université Pierre et Marie Curie, Paris, France
}

Correspondence to: F. Planchon (frederic.planchon@univ-brest.fr)

Received: 20 February 2012 - Published in Biogeosciences Discuss.: 19 March 2012

Revised: 19 December 2012 - Accepted: 29 December 2012 - Published: 6 February 2013

\begin{abstract}
As part of the GEOTRACES Bonus-GoodHope (BGH) expedition (January-March 2008) in the Atlantic sector of the Southern Ocean, particulate organic carbon (POC) export was examined from the surface to the mesopelagic twilight zone using water column distributions of total ${ }^{234} \mathrm{Th}$ and biogenic particulate $\mathrm{Ba}\left(\mathrm{Ba}_{\mathrm{xs}}\right)$. Surface POC export production was estimated from steady state and non steady state modelling of ${ }^{234} \mathrm{Th}$ fluxes, which were converted into POC fluxes, using the POC/234 $\mathrm{Th}$ ratio of large, potentially sinking particles $(>53 \mu \mathrm{m})$ collected via in situ pumps. Deficits in ${ }^{234} \mathrm{Th}$ activities were observed at all stations from the surface to the bottom of the mixed layer, yielding ${ }^{234} \mathrm{Th}$ export fluxes from the upper $100 \mathrm{~m}$ of $496 \pm 214 \mathrm{dpm} \mathrm{m}^{-2} \mathrm{~d}^{-1}$ to $1195 \pm 158 \mathrm{dpm} \mathrm{m}^{-2} \mathrm{~d}^{-1}$ for the steady state model and of $149 \pm 517 \mathrm{dpm} \mathrm{m}^{-2} \mathrm{~d}^{-1}$ to $1217 \pm 231 \mathrm{dpm} \mathrm{m}^{-2} \mathrm{~d}^{-1}$ for the non steady state model. Using the $\mathrm{POC} /{ }^{234} \mathrm{Th}_{\mathrm{p}}$ ratio of sinking particles (ratios varied from $1.7 \pm 0.2 \mu \mathrm{mol} \mathrm{dpm}^{-1}$ to $4.8 \pm 1.9 \mu \mathrm{mol} \mathrm{dpm}^{-1}$ ) POC export production at $100 \mathrm{~m}$ was calculated to range between $0.9 \pm 0.4$ and $5.1 \pm 2.1 \mathrm{mmol} \mathrm{C} \mathrm{m}^{-2} \mathrm{~d}^{-1}$, assuming steady state and between $0.3 \pm 0.9 \mathrm{~m}^{-2} \mathrm{~d}^{-1}$ and $4.9 \pm 3.3 \mathrm{mmol} \mathrm{C} \mathrm{m}^{-2} \mathrm{~d}^{-1}$, assuming non steady state. From the comparison of both approaches, it appears that during late summer export decreased by 56 to $16 \%$ for the area between the sub-Antarctic zone and the southern Antarctic Circumpolar Current Front (SACCF), whereas it remained rather constant over time in the HNLC area south of the SACCF. POC export represented
\end{abstract}

only 6 to $54 \%$ of new production, indicating that export efficiency was, in general, low, except in the vicinity of the SACCF, where export represented $56 \%$ of new production.

Attenuation of the POC sinking flux in the upper mesopelagic waters (100-600 m depth interval) was evidenced both, from excess ${ }^{234} \mathrm{Th}$ activities and from particulate biogenic $\mathrm{Ba}\left(\mathrm{Ba}_{\mathrm{xs}}\right)$ accumulation. Excess ${ }^{234} \mathrm{Th}$ activities, reflected by ${ }^{234} \mathrm{Th} /{ }^{238} \mathrm{U}$ ratios as large as $1.21 \pm 0.05$, are attributed to remineralisation/disaggregation of ${ }^{234} \mathrm{Th}$-bearing particles. The accumulation of excess ${ }^{234} \mathrm{Th}$ in the $100-600 \mathrm{~m}$ depth interval ranged from $458 \pm 633 \mathrm{dpm} \mathrm{m}^{-2} \mathrm{~d}^{-1}$ to $3068 \pm 897 \mathrm{dpm} \mathrm{m}^{-2} \mathrm{~d}^{-1}$, assuming steady state. Using the $\mathrm{POC}^{234} \mathrm{Th}_{\mathrm{p}}$ ratio of sinking particles $(>53 \mu \mathrm{m})$, this ${ }^{234} \mathrm{Th}$ accumulation flux was converted into a POC remineralisation flux which ranged between $0.9 \pm 1.2 \mathrm{mmol} \mathrm{C} \mathrm{m}^{-2} \mathrm{~d}^{-1}$ and $9.2 \pm 2.9 \mathrm{mmol} \mathrm{C} \mathrm{m}^{-2} \mathrm{~d}^{-1}$. Mesopelagic particulate biogenic $\mathrm{Ba}$ has been reported to reflect bacterial degradation of organic matter and to be related to oxygen consumption and bacterial carbon respiration. We observed that the highest $\mathrm{Ba}_{\mathrm{xs}}$ contents (reaching up to $>1000 \mathrm{pM}$ ), in general, occurred between 200 and $400 \mathrm{~m}$. Depth-weighted average mesopelagic $\mathrm{Ba}_{\mathrm{xs}}$ (meso- $\mathrm{Ba}_{\mathrm{xs}}$ ) values were converted into respired $\mathrm{C}$ fluxes, which ranged between 0.23 and $6.4 \mathrm{mmol} \mathrm{C} \mathrm{m}^{-2} \mathrm{~d}^{-1}$, in good agreement with ${ }^{234} \mathrm{Th}$-based remineralisation fluxes. A major outcome from this study is the observed significant positive correlation between POC 
remineralisation as estimated from meso- $\mathrm{Ba}_{\mathrm{xs}}$ contents and from ${ }^{234} \mathrm{Th}$ excess $\left(R^{2}=0.73\right.$; excluding 2 outliers). Remineralisation of POC in the twilight zone was particularly efficient relative to POC export resulting in negligible bathypelagic $(>600 \mathrm{~m})$ POC export fluxes in the sub-Antarctic zone, the Polar Front zone and the northern Weddell Gyre, while the subtropical zone as well as the vicinity of the SACCF had significant deep POC fluxes.

\section{Introduction}

The Southern Ocean (SO) is recognized for playing a central role in the global regulation of atmospheric $\mathrm{CO}_{2}$, at time scales varying from intra-annual, decadal, and up to glacial/interglacial fluctuations (de Boer et al., 2010; Gruber et al., 2009; Sigman and Boyle, 2000; Takahashi et al., 2009). This results from its peculiar physical (low temperatures, occurrence of large upwelling and subduction areas) and biogeochemical properties since it represents a huge reservoir of unused macronutrients (e.g. Takahashi et al., 2009; Sarmiento et al., 2004). These properties impact the dissolved inorganic carbon (DIC) distribution (solubility pump) and the production of sinking particles by marine organisms (biological pump) (Takahashi et al., 2002). During the last two decades the SO has been intensively studied in order to better quantify spatial and temporal variabilities of the biological pump (Boyd and Trull, 2007; Boyd, 2002; Buesseler et al., 2001, 2003; Rutgers van der Loeff et al., 1997; Trull et al., 2001, 2008). Also, the sub-Antarctic zone where the biological pump dominates the seasonal carbon budget has recently attracted renewed attention (Bowie et al., 2011; McNeil and Tilbrook, 2009; Metzl et al., 1999).

Significant carbon export production based on ${ }^{234} \mathrm{Th}$ activity, new production and seasonal nutrient budgets, has been reported, though SO primary production is relatively low (Buesseler et al., 2001, 2009; Coppola et al., 2005; Friedrich and Rutgers van der Loeff, 2002; Nelson et al., 2002; Pondaven et al., 2000; Savoye et al., 2004b; Usbeck et al., 2002). High surface export production, which can account for up to $30-50 \%$ of the net primary production (NPP), could be partly related to seasonal blooms of diatoms (Rutgers van der Loeff et al., 1997, 2002). However, this $C$ export is usually strongly attenuated at greater depth, as witnessed by observations of particulate biogenic barium accumulation (Cardinal et al., 2005; Dehairs et al., 1997; Jacquet et al., 2008a) and excess ${ }^{234} \mathrm{Th}$ activity (Savoye et al., 2004a; Usbeck et al., 2002) in mesopelagic waters. Despite these substantial progresses, the SO remains an oceanic region largely unresolved in terms of observations and experiments, and therefore, large discrepancies between model estimates persist (Gruber et al., 2009; McNeil et al., 2007). Better constraining the processes that favor long-term sequestration of carbon in the Austral Ocean still represents a major scientific issue.
Here, we report new estimates of late summer POC export flux for the Atlantic sector of the Southern Ocean, along a transect from the Cape Basin to the northern Weddell Gyre, as part of the Bonus-GoodHope (BGH) program during the International Polar Year, 2008. Our aims are to examine surface POC export production and mesopelagic remineralisation, using water column distributions of total ${ }^{234} \mathrm{Th}$ and biogenic particulate $\mathrm{Ba}\left(\mathrm{Ba}_{\mathrm{xs}}\right)$, and to deduce deep ocean $\mathrm{C}$ sequestration fluxes. The observed trends are discussed for the different biogeochemical provinces crossed by the BGH section between the subtropical zone and the northern branch of the Weddell Gyre.

The POC export fluxes were inferred from measurements of the short-lived radionuclide ${ }^{234} \mathrm{Th}\left(t_{1 / 2}=24.1 \mathrm{~d}\right)$, which is now recognized as a robust proxy of the short-term dynamics of biogenic particles (Cochran and Masqué, 2003; Waples et al., 2006). Naturally occurring ${ }^{234} \mathrm{Th}$ is the decay product of ${ }^{238} \mathrm{U}$, which is conservatively distributed in the open ocean, proportional to salinity (Chen et al., 1986; Owens et al., 2011; Pates and Muir, 2007). Unlike ${ }^{238} \mathrm{U}$, ${ }^{234} \mathrm{Th}$ has a strong affinity for particulate matter and its activity distribution through the water column offers a means for quantifying export flux and aggregation/disaggregation of particles on regional and seasonal scales (Buesseler et al., 1992). Fluxes of ${ }^{234} \mathrm{Th}$ are combined with the measured ratio of $\mathrm{POC} /{ }^{234} \mathrm{Th}$ of sinking particles in order to quantify upper ocean and mesopelagic export of POC (Cochran and Masqué, 2003; Maiti et al., 2010; Savoye et al., 2004a). We also report mesopelagic carbon remineralisation fluxes estimated from excess $\mathrm{Ba}\left(\mathrm{Ba}_{\mathrm{xs}}\right.$; particulate $\mathrm{Ba}$ corrected for the lithogenic contribution). $\mathrm{Ba}_{\mathrm{xs}}$ profiles in the open ocean are characterized by maximum concentrations in the upper mesopelagic $(\sim 150-500 \mathrm{~m})$. This $\mathrm{Ba}_{\mathrm{xs}}$ is mostly present under the form of micro-crystralline barite $\left(\mathrm{BaSO}_{4}\right)$ (Dehairs et al., 1980; Sternberg et al., 2008) and its formation is related to the decay of phytoplankton. Barite is precipitated in oversaturated micro-environments, mostly aggregates of organic material where bacterial activity is intense (Ganeshram et al., 2003). When micro-environments disintegrate and become remineralised in the mesopelagic zone, discrete barite crystals are released and the $\mathrm{Ba}_{\mathrm{xs}}$ content can be related to carbon remineralisation activity (van Beek et al., 2009; Jacquet et al., 2008a; 2011; Sternberg et al., 2008). The time scale involved in this process can represent a few days to a few weeks (Ganeshram et al., 2003; Cardinal et al., 2005; Jacquet et al., 2008b).

\section{Materials and methods}

\subsection{Study area}

The Bonus-GoodHope expedition (8 February-24 March, 2008; R/V Marion Dufresne) studied a section from the Cape Basin till the northern Weddell Gyre. Locations of the 
stations and position of major hydrographic fronts encountered are shown in Fig. 1. Starting from the subtropical domain, the cruise track crossed the southern Subtropical Front (S-STF), the sub-Antarctic Front (SAF), the Polar Front (PF), the southern Antarctic Circumpolar Current Front (SACCF), and finally the southern boundary of the ACC (Sbdy). Eleven stations were sampled for total ${ }^{234} \mathrm{Th}$ activity. Among these, five stations were also sampled for particulate ${ }^{234} \mathrm{Th}$ (S1 to $\mathrm{S} 5$ ) in order to obtain $\mathrm{POC} /{ }^{234} \mathrm{Th}$ ratios of sinking particulate matter. Eight stations were sampled for the $\mathrm{Ba}_{\mathrm{xs}}$ proxy ( $\mathrm{S} 1$ to S5 and L3, L5 and L7).

\subsection{Determination of total ${ }^{234} \mathrm{Th}$ activity}

Total ${ }^{234} \mathrm{Th}$ activities were obtained from small volume $(4 \mathrm{~L})$ seawater samples collected from $12 \mathrm{~L}$ Niskin bottles. As detailed in Supplement 1, the samples for "Super" stations (S1 to S5) were taken at 19-20 depths between the surface and $1000 \mathrm{~m}$ depth. For Large stations L2 $\left(41.18^{\circ} \mathrm{S}\right)$, L4 $\left(46.02^{\circ} \mathrm{S}\right)$ and $\mathrm{L} 6\left(50.38^{\circ} \mathrm{S}\right)$, samples were collected at 5, 9 and 8 depths between surface and 300, 200 and $250 \mathrm{~m}$ depth, respectively. For large stations L3, L5 and L7, 15-17 samples were collected between the surface and $1000 \mathrm{~m}$ depth. For calibration purposes, we considered eight samples taken at $1000 \mathrm{~m}$ depth at stations S1, L2, L3, S3, L5, S4, L7 and S5. In addition, deep samples were taken at $1500 \mathrm{~m}$ and $4400 \mathrm{~m}$ depth at station L2, at $1500 \mathrm{~m}$ depths at station S2 (duplicates), at $2000 \mathrm{~m}$ and $4100 \mathrm{~m}$ at $\mathrm{L} 3$.

Seawater samples were processed for total ${ }^{234} \mathrm{Th}$ activity measurement following the procedure developed by Pike et al. (2005). Briefly, samples were acidified (pH 2), spiked with ${ }^{230} \mathrm{Th}$ yield tracer, and left for 12 hours equilibration before co-precipitation with $\mathrm{Mn}$ ( $\mathrm{pH}$ 8.5). Samples were filtered on high-purity quartz microfiber filters (QMA, Sartorius; nominal pore size $=1 \mu \mathrm{m}$; $\varnothing 25 \mathrm{~mm}$ ), dried overnight and mounted on nylon filter holders. On board samples were counted twice using a low level beta counter (RIS $\varnothing$, Denmark). Beta counting was continued till counting uncertainty was below 2\% RSD (relative standard deviation). Residual beta activity was counted for each sample after a delay of six ${ }^{234} \mathrm{Th}$ half-lives ( $\sim 6$ months) and was subtracted from the gross counts recorded on-board.

For Th recovery, filters were dismounted and $\mathrm{MnO}_{2}$ precipitates dissolved in $10 \mathrm{~mL} 8 M \mathrm{HNO}_{3} / 10 \% \mathrm{H}_{2} \mathrm{O}_{2}$ solution and spiked with ${ }^{229} \mathrm{Th}$ as a second yield tracer. Dissolved samples were sonicated for $1 \mathrm{~h}$, heated overnight $\left(60^{\circ} \mathrm{C}\right)$, filtered using Acrodisc $0.2 \mu \mathrm{m}$ syringe filters, and stored in clean $30 \mathrm{~mL}$ HDPE (high-density polyethylene) bottles, before analysis. Prior to analysis samples were diluted 10 to 20 times using $10 \%$ nitric acid $10 \%$ without any further purification. Determination of ${ }^{230} \mathrm{Th} /{ }^{229} \mathrm{Th}$ ratios was carried out by HR-ICP-MS (high resolution-inductively coupled plasma-mass spectrometry) (Element2, Thermo Electron) with low mass resolution settings $(M / \Delta M: \sim 300)$ and hot plasma conditions (RF power: $1300 \mathrm{~W}$ ). Samples were intro-

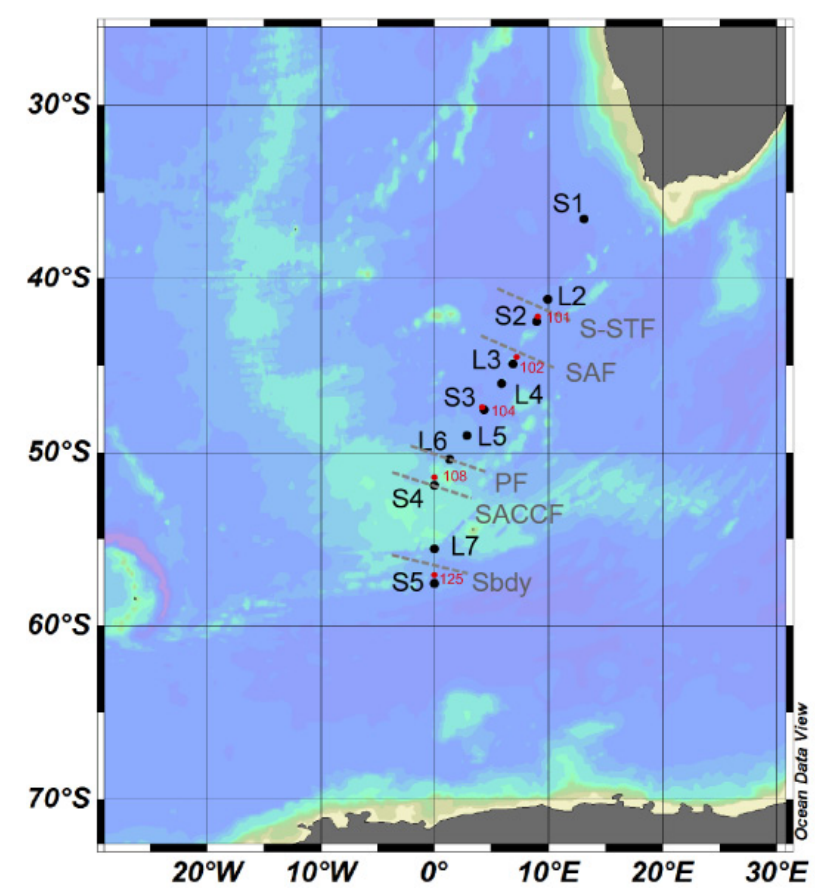

Fig. 1. Station location along the Bonus-GoodHope section (black dots); red dots are sites sampled for ${ }^{234}$ Th during the ANTXXIV/3 expedition (see text). Also shown are the different frontal zones crossed during the BGH cruise: the southern Subtropical Front (S-STF), the sub-Antarctic Front (SAF), the Polar Front (PF), the southern ACC Front (SACCF) and the southern boundary (Sbdy). Schlitzer, 2003; Ocean Data View; http://www.awi-bremerhaven. de/GEO/ODV.

duced in the plasma using a Peltier cooled $\left(5^{\circ} \mathrm{C}\right)$ cyclonic spray chamber fitted with a $400 \mu \mathrm{L} \mathrm{min}^{-1}$ glass micro nebulizer. Mass calibration and sensitivity tuning were carried out daily. Preliminary tests performed with standard solutions, which had a matrix similar to those of the samples in terms of Mn levels, were spiked with ${ }^{230} \mathrm{Th}$ and ${ }^{229} \mathrm{Th}$ and digested using $8 \mathrm{M} \mathrm{HNO}_{3} / 10 \% \mathrm{H}_{2} \mathrm{O}_{2}$, showed that ICP-MS performances were unaffected by any matrix effect. Measurement uncertainty in terms of relative standard deviation (RSD) of the ${ }^{230} \mathrm{Th} /{ }^{229} \mathrm{Th}$ ratios ranged from 0.1 to $1.6 \%(n=3$ replicates) with dilution factors of 5 to 20 . Estimated reproducibility of the method, evaluated with 9 standard solutions prepared separately and determined over different analytical sessions, was also particularly good and ranged from 0.5 to $1.3 \%$. The precision obtained with this simplified procedure meets the requirements defined by Pike et al. (2005), who emphasize the need to achieve ${ }^{229} \mathrm{Th} /{ }^{230} \mathrm{Th}$ ratio errors of $\leq 2 \%$ in order to reach accurate ${ }^{234} \mathrm{Th}$ activities. Th recoveries were estimated for every sample processed $(n=175)$ and measurement precision as obtained from triplicate analyses were all below $2 \%$ RSD. Average Th recovery was $87 \pm 2 \%$ $(n=175)$. Uncertainties on total ${ }^{234} \mathrm{Th}$ activity are reported in Supplement 1 and represent on average $0.10 \mathrm{dpm} \mathrm{L}^{-1}$. 
The parent ${ }^{238} \mathrm{U}$ activity was estimated with salinity measurements using the relationship of Pates and Muir (2007): ${ }^{238} \mathrm{U}\left(\mathrm{dpm} \mathrm{L} \mathrm{L}^{-1}\right)=(0.0713 \pm 0.0012) \times$ Salinity. Overall accuracy of the method was evaluated from the deep water samples taken along the section between 1000 and $4400 \mathrm{~m}$ depth, and for which secular equilibrium between ${ }^{234} \mathrm{Th}$ and ${ }^{238} \mathrm{U}$ can reasonably be expected. Standard deviation of the mean ${ }^{234} \mathrm{Th} /{ }^{238} \mathrm{U}$ ratio obtained for deep waters was $0.031 \mathrm{dpm} \mathrm{L}^{-1}(n=14)$.

\section{$2.3 \quad{ }^{234}$ Th flux and models}

${ }^{234} \mathrm{Th}$ flux was estimated from total ${ }^{234} \mathrm{Th}$ and ${ }^{238} \mathrm{U}$ activities using a one-box model. The one-box model accounts for total ${ }^{234} \mathrm{Th}$ activity balance (Savoye et al., 2006), and changes over time can be described using the following equation:

$\frac{\mathrm{d} A_{\mathrm{Th}}}{\mathrm{d} t}=\lambda\left(A_{\mathrm{U}}-A_{\mathrm{Th}}\right)-P$

Where $\lambda$ is the ${ }^{234}$ Th decay constant $\left(0.0288 \mathrm{~d}^{-1}\right) ; A_{\mathrm{U}}$ and $A_{\text {Th }}$ represent total ${ }^{238} \mathrm{U}$ and ${ }^{234} \mathrm{Th}$ activities, respectively; $P$ is the net loss of ${ }^{234} \mathrm{Th}$ on sinking particles (i.e. vertical ${ }^{234} \mathrm{Th}$ flux) expressed in $\mathrm{dpm} \mathrm{m}^{-2} \mathrm{~d}^{-1}$. In this equation, advective and diffusive fluxes are neglected (Savoye et al., 2006) and the vertical flux of ${ }^{234} \mathrm{Th}(P)$ can be estimated using the steady state (SS) approach. A first calculation was made using the SS assumption. Detailed equation can be found elsewhere (Savoye et al., 2006).

High resolution profiles of ${ }^{234} \mathrm{Th}$ activity in the upper $1000 \mathrm{~m}$ allow the export flux to be estimated from the upper ocean (surface export) as well as from the mesopelagic zone at $600 \mathrm{~m}$ depth (mesopelagic export). Integration of ${ }^{234} \mathrm{Th}$ activity along the water column was performed using a midpoint integration method. ${ }^{234} \mathrm{Th}$ surface export flux was also estimated using the non steady state (NSS) model.

This was possible because another cruise (ANTXXIV/3, R/V Polarstern) preceded the BGH cruise by 14 to 22 days and followed exactly the same section (Zero Meridian, see Fig. 1). Sites with ${ }^{234} \mathrm{Th}$ activities measured during the ANTXXIV/3 cruise matched with 6 out of the 11 sites sampled during BGH (Rutgers van der Loeff et al., 2011). ANTXXIV/3 results for these sites were considered initial ${ }^{234} \mathrm{Th}$ activities for the NSS approach. Equation used for NSS export flux estimates can be found elsewhere (Savoye et al., 2006).

\subsection{Measurements of particulate ${ }^{234} \mathrm{Th}$ and POC}

For particulate ${ }^{234} \mathrm{Th}$ and POC, suspended particulate matter was collected at five stations (S1, S2, S3, S4 and S5) via in situ large-volume filtration (150-2000 L) systems (Challenger Oceanics and McLane WTS6-1-142LV pumps) equipped with $142 \mathrm{~mm}$ diameter filter holders. Two particle size classes ( $>53 \mu \mathrm{m}$ and $1-53 \mu \mathrm{m}$ ) were collected via sequential filtration through a $53 \mu \mathrm{m}$ mesh nylon screen
(SEFAR-PETEX $^{\circledR}$; polyester) and a $1 \mu \mathrm{m}$ pore size quartz fiber filter (QMA, Pall Life). Because suspended particles were also intended for analysis of ${ }^{14} \mathrm{C}_{\mathrm{POC}}$ and ${ }^{210} \mathrm{~Pb} /{ }^{210} \mathrm{Po}$ and biomarkers by other participants, the filters were preconditioned prior to sampling. The PETEX screens were soaked in $\mathrm{HCl} 5 \%$, rinsed with Milli-Q grade water, dried at ambient temperature in a laminar flow hood and stored in clean plastic bags. QMA filters were precombusted at $450^{\circ} \mathrm{C}$ during $4 \mathrm{~h}$ and filters were stored in clean plastic bags before use.

After collection, filters were subsampled for the different end-users using sterile scalpels, a custom-build inox steel support for $53 \mu \mathrm{m}$ PETEX screens and a plexiglas punch of $25 \mathrm{~mm}$ diameter for QMA filters. For large size particles $(>53 \mu \mathrm{m})$, particles on the PETEX screen parts dedicated to ${ }^{234} \mathrm{Th}$ were re-suspended in filtered seawater in a laminar flow hood, and collected on $25 \mathrm{~mm}$ diameter silver filters (1.0 $\mu \mathrm{m}$ porosity). Silver and QMA filters were dried overnight, and once mounted on nylon holders and covered with Mylar and aluminum foil, were ready for beta counting. As for total ${ }^{234} \mathrm{Th}$ activity, particulate samples were counted twice on board until relative standard deviation was below $2 \%$. Residual beta activity was measured in the home-based laboratory after six ${ }^{234} \mathrm{Th}$ half-lives ( $\sim 6$ months).

Following beta counting, particulate samples (QMA and $\mathrm{Ag}$ filters) were processed for POC measurement by elemental analyser - isotope ratio mass spectrometer (EA-IRMS). Size-fractionated samples were dismounted from filter holders and fumed under $\mathrm{HCl}$ vapor during $4 \mathrm{~h}$ inside a glass desiccator, to remove the carbonate phase. After overnight drying at $50^{\circ} \mathrm{C}$, samples were packed in silver cups and analysed with a Carlo Erba NA 2100 elemental analyser configured for $\mathrm{C}$ analysis and coupled on-line via a Con-Flo III interface to a Thermo-Finnigan Delta $V$ isotope ratio mass spectrometer. Acetanilide standard was used for $\mathrm{C}$ concentration calibration and $\mathrm{C}$ blanks were $0.98 \mu \mathrm{mol}$ and $0.54 \mu \mathrm{mol}$ for QMA and silver filters, respectively. Results obtained for bulk POC and two size-segregated POC fractions $(>53 \mu \mathrm{m}$ and $1-53 \mu \mathrm{m})$ are reported in Table 1 along with particulate ${ }^{234} \mathrm{Th}$ activity measured on the same samples.

\subsection{Ba $\mathrm{a}_{\mathrm{xs}}$ sampling and measurements}

Nineteen to twenty depths were sampled in the upper $1000 \mathrm{~m}$ using the CTD rosette equipped with $12 \mathrm{~L}$ Niskin bottles. $5-10 \mathrm{~L}$ of seawater was filtered onto $0.4 \mu \mathrm{m}$ polycarbonate membranes ( $\varnothing 90 \mathrm{~mm}$ for surface samples and $47 \mathrm{~mm}$ for the other depths) using large volume Perspex filtration units under slight overpressure supplied by filtered air $(0.4 \mu \mathrm{m})$. Membranes were rinsed with a few $\mathrm{mL}$ of Milli-Q grade water to remove most of the sea salt, dried overnight in the oven at $\sim 60^{\circ} \mathrm{C}$ and then stored in plastic Petri dishes. Filtration blanks were prepared on-board by filtering $5 \mathrm{~L}$ of Milli-Q water and applying the same conditions as for the samples. 
Table 1. ${ }^{234}$ Th export fluxes $\left(\mathrm{dpm} \mathrm{m} \mathrm{m}^{-2} \mathrm{~d}^{-1}\right)$ along the BGH section as calculated using steady state and non steady state models. Uncertainty associated with ${ }^{234} \mathrm{Th}$ flux is at $95 \%$ confidence interval $(2 \sigma)$. STZ: subtropical zone; STF: Subtropical Front; SAZ: sub-Antarctic zone; SAF: sub-Antarctic Front; PFZ: polar frontal zone; PF: Polar Front; SACCF: southern Antarctic Circumpolar Current Front; AZ: Antarctic zone; WG: Weddell Gyre.

\begin{tabular}{|c|c|c|c|c|c|c|c|c|c|c|c|c|c|}
\hline \multirow[b]{3}{*}{ Station } & \multirow[b]{3}{*}{ Lat } & \multirow[b]{3}{*}{ Lon } & \multirow[b]{3}{*}{ Zone } & \multirow[b]{3}{*}{ Sampling date } & \multirow[b]{3}{*}{$\begin{array}{l}\text { ML depth* } \\
\quad(\mathrm{m})\end{array}$} & \multirow{2}{*}{\multicolumn{2}{|c|}{$\begin{array}{c}\text { Steady State Model } \\
{ }^{234} \text { Th export flux }\end{array}$}} & \multicolumn{6}{|c|}{ Non Steady State Model } \\
\hline & & & & & & & & \multicolumn{5}{|c|}{ 1st Visit (Cruise ANTXXIV/3) } & \multirow{2}{*}{$\begin{array}{c}{ }^{234} \text { Th export flux } \\
\text { at } 100 \mathrm{~m} \\
\left(\mathrm{dpm} \mathrm{m} \mathrm{m}^{-2} \mathrm{~d}^{-1}\right)\end{array}$} \\
\hline & & & & & & $\begin{array}{c}\text { at } 100 \mathrm{~m} \\
\left(\mathrm{dpm} \mathrm{m}^{-2} \mathrm{~d}^{-1}\right)\end{array}$ & $\begin{array}{c}\text { at ML depth } \\
\left(\mathrm{dpm} \mathrm{m} \mathrm{m}^{-2} \mathrm{~d}^{-1}\right)\end{array}$ & Station & Lat & Lon & $\begin{array}{l}\text { Sampling } \\
\text { date }\end{array}$ & $\begin{array}{l}\text { Time } \\
\text { elapsed } \\
\text { (day) }\end{array}$ & \\
\hline S1 & $36.5^{\circ} \mathrm{S}$ & $13.1^{\circ} \mathrm{E}$ & STZ & $2 / 21 / 2008$ & 50 & $926 \pm 137$ & $731 \pm 111$ & & & & & & \\
\hline L2 & $41.2^{\circ} \mathrm{S}$ & $9.0^{\circ} \mathrm{E}$ & STF & $2 / 26 / 2008$ & 25 & $496 \pm 214$ & $388 \pm 78$ & & & & & & \\
\hline $\mathrm{S} 2$ & $42.5^{\circ} \mathrm{S}$ & $8.9^{\circ} \mathrm{E}$ & SAZ & $2 / 27 / 2008$ & 65 & $986 \pm 138$ & $958 \pm 106$ & 101 & $42.2^{\circ} \mathrm{S}$ & $8.9^{\circ} \mathrm{E}$ & $2 / 13 / 2008$ & 14.9 & $149 \pm 517$ \\
\hline L3 & $44.9^{\circ} \mathrm{S}$ & $6.9^{\circ} \mathrm{E}$ & SAF & $3 / 1 / 2008$ & 70 & $987 \pm 107$ & $1118 \pm 107$ & 102 & $44.4^{\circ} \mathrm{S}$ & $7.0^{\circ} \mathrm{E}$ & $2 / 15 / 2008$ & 15.7 & $530 \pm 253$ \\
\hline L4 & $46.0^{\circ} \mathrm{S}$ & $5.9^{\circ} \mathrm{E}$ & PFZ & $3 / 3 / 2008$ & 80 & $871 \pm 116$ & $839 \pm 111$ & & & & & & \\
\hline S3 & $47.5^{\circ} \mathrm{S}$ & $4.4^{\circ} \mathrm{E}$ & PFZ & $3 / 5 / 2008$ & 90 & $1086 \pm 111$ & $1086 \pm 108$ & 104 & $47.4^{\circ} \mathrm{S}$ & $4.3^{\circ} \mathrm{E}$ & $2 / 16 / 2008$ & 18.7 & $447 \pm 151$ \\
\hline L5 & $49.0^{\circ} \mathrm{S}$ & $2.8^{\circ} \mathrm{E}$ & PFZ & $3 / 7 / 2008$ & 120 & $1160 \pm 104$ & $1521 \pm 116$ & & & & & & \\
\hline L6 & $50.4^{\circ} \mathrm{S}$ & $1.3^{\circ} \mathrm{E}$ & $\mathrm{PF}$ & $3 / 9 / 2008$ & 100 & $1195 \pm 158$ & $1195 \pm 158$ & & & & & & \\
\hline S4 & $51.9^{\circ} \mathrm{S}$ & $0.0^{\circ} \mathrm{E}$ & SACCF & $3 / 11 / 2008$ & 120 & $1073 \pm 124$ & $1422 \pm 141$ & 108 & $51.3^{\circ} \mathrm{S}$ & $0.0^{\circ} \mathrm{E}$ & $2 / 19 / 2008$ & 21.1 & $365 \pm 155$ \\
\hline L7 & $55.2^{\circ} \mathrm{S}$ & $0.0^{\circ} \mathrm{E}$ & $\mathrm{AZ}$ & $3 / 14 / 2008$ & 105 & $1072 \pm 175$ & $1128 \pm 175$ & 118 & $54.3^{\circ} \mathrm{S}$ & $0.0^{\circ} \mathrm{E}$ & $2 / 21 / 2008$ & 22.3 & $1217 \pm 231$ \\
\hline S5 & $57.6^{\circ} \mathrm{S}$ & $0.0^{\circ} \mathrm{E}$ & WG & $3 / 16 / 2008$ & 90 & $800 \pm 130$ & $800 \pm 103$ & 125 & $57.0^{\circ} \mathrm{S}$ & $0.0^{\circ} \mathrm{E}$ & $2 / 23 / 2008$ & 22.8 & $757 \pm 165$ \\
\hline
\end{tabular}

* Mixed-layer depth determined from the vertical profile of temperature for nearby CTD and taken from Chever et al. (2010).

Particles were digested with a tri-acid mixture $\left(1.5 \mathrm{~mL} \mathrm{HCl} 30 \%, 1.0 \mathrm{~mL} \mathrm{HNO}_{3} 65 \%\right.$ and $0.5 \mathrm{~mL} \mathrm{HF}$ $40 \%$, all Suprapur grade) in closed teflon beakers overnight at $90{ }^{\circ} \mathrm{C}$. After evaporation close to dryness samples were redissolved into $\sim 13 \mathrm{~mL}$ of $\mathrm{HNO}_{3} 2 \%$. The solutions were analysed by ICP-MS X Series 2 (Thermo) equipped with a collision cell technology (CCT). Ba, $\mathrm{Na}$ and $\mathrm{Al}$ contents were analysed simultaneously (with CCT for Al and without for $\mathrm{Ba}$ and $\mathrm{Na})$. To check whether internal standards $\left({ }^{99} \mathrm{Ru}\right.$, ${ }^{115} \mathrm{In},{ }^{187} \mathrm{Re},{ }^{209} \mathrm{Bi}$ ) adequately corrected possible matrix effects, we analysed several certified materials which also served to construct calibration curves. These standards solutions consisted of dilute acid-digested rocks (BHVO-1, GA, SGR-1), natural water (SLRS-4) and multi-element artificial solutions. Based on analyses of these standards, precision, accuracy and reproducibility are better than $\pm 5 \%$. For more details on sample processing and analysis we refer to Cardinal et al. (2001). Detection limit in solution was calculated as three times the standard deviation of the on-board blanks and reaches 20 and $0.5 \mathrm{ppb}$ for $\mathrm{Al}$ and $\mathrm{Ba}$, respectively. $\mathrm{BGH}$ samples are largely exceeding this detection limit for $\mathrm{Ba}$ and on-board filtration blanks represented only $2 \pm 0.8 \%$ of the average sample Ba content. For Al, 23 over a total of 160 samples are below detection limit, but concentrations are most of the time very close to the detection limit. Indeed, $\mathrm{Al}$ for on-board blanks represents $28 \pm 14 \%$ of average sample Al content. However, this did not significantly affect the obtained values for $\mathrm{Ba}_{\mathrm{xs}}$ concentration and remineralisation flux, as discussed later.

Values of on-board prepared blanks were subtracted from sample values and excess $\mathrm{Ba}$ calculated by correcting total $\mathrm{Ba}$ for the lithogenic Ba contribution, using sample $\mathrm{Al}$ content and a Ba:Al crustal molar ratio of 0.00135 (Taylor et McLennan, 1985). Na was also analysed to correct any sea- salt contribution to $\mathrm{Ba}_{\mathrm{xs}}$. Remnant sea-salt was found to have but a negligible effect on $\mathrm{Ba}_{\mathrm{xs}}$.

\subsection{Carbon flux calculations from $\mathrm{Ba}_{\mathrm{xs}}$ depth profiles}

Remineralisation carbon fluxes can be estimated using a relationship observed in ACC waters between meso- $\mathrm{Ba}_{\mathrm{xs}}$ contents and the rate of oxygen consumption deduced from a 1-D advection diffusion model (Dehairs et al., 1997, 2008; Shopova et al., 1995):

$J_{\mathrm{O}_{2}}=\left(\right.$ mesoBa $\left._{\mathrm{xs}}-\mathrm{Ba}_{\text {residual }}\right) / 17450$,

where $J_{\mathrm{O}_{2}}$ is the $\mathrm{O}_{2}$ consumption $\left(\mu \mathrm{mol} \mathrm{L} \mathrm{L}^{-1} \mathrm{~d}^{-1}\right)$, meso$\mathrm{Ba}_{\mathrm{xs}}$ is the observed depth-weighted average $\mathrm{Ba}_{\mathrm{xs}}$ value in the upper mesopelagic waters (125 to $600 \mathrm{~m}$ depth interval) and $\mathrm{Ba}_{\text {residual }}$ is the residual $\mathrm{Ba}_{\mathrm{xs}}$ signal at zero oxygen consumption. For the $\mathrm{BaSO}_{4}$ saturated water column of the ACC this residual $\mathrm{Ba}_{\mathrm{xs}}$ was estimated to reach $180 \mathrm{pM}$ (Monnin and Cividini, 2006; Monnin et al., 1999). Such a value is expected also to prevail in deep waters $(>600 \mathrm{~m})$ where remineralisation is minimal compared to the upper mesopelagic. In the present study deep ocean $\mathrm{Ba}_{\mathrm{xs}}$ values $(800-1000 \mathrm{~m}$ ) are generally close to $200 \mathrm{pM}$. This also holds for the deep SAZ and the STZ waters (stations S1, S2 and L3), known to be undersaturated for $\mathrm{BaSO}_{4}$ (Monnin and Cividini, 2006; Monnin et al., 1999) and which therefore are expected to have smaller residual $\mathrm{Ba}_{\mathrm{xs}}$ contents. Since that is not observed here, we choose to apply a single value of $180 \mathrm{pM}$ for $\mathrm{Ba}_{\text {residual }}$ at all stations.

Calculated $J_{\mathrm{O}_{2}}$ was then converted into carbon respired $\left(\mathrm{C}_{\text {respired }}\right)$ by:

$\mathrm{C}_{\text {respired }}=Z \times J_{\mathrm{O}_{2}} \times \mathrm{RR}$.

$\mathrm{C}_{\text {respired }}$ is the organic carbon remineralisation rate (in mmol $\left.\mathrm{C} \mathrm{m}^{-2} \mathrm{~d}^{-1}\right), Z$ is the thickness of the mesopelagic 

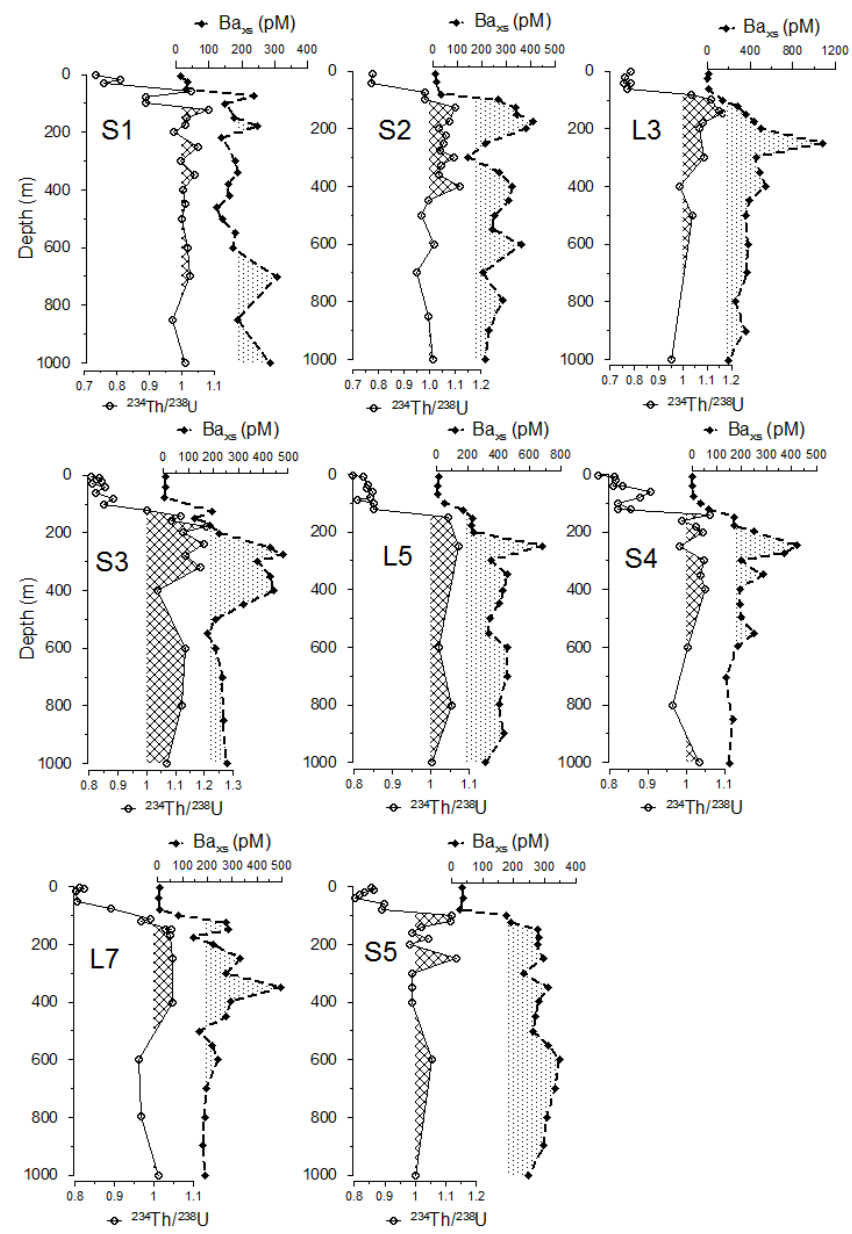

Fig. 2. Vertical distribution of ${ }^{234} \mathrm{Th} /{ }^{238} \mathrm{U}$ ratios and biogenic particulate $\mathrm{Ba}\left(\mathrm{Ba}_{\mathrm{xs}} ; \mathrm{pM}\right)$ between surface and $1000 \mathrm{~m}$ depth along the BGH section. Hatched and dotted areas stand for ${ }^{234}$ Th excess relative to ${ }^{238} \mathrm{U}$ and biogenic particulate $\mathrm{Ba}\left(\mathrm{Ba}_{\mathrm{xs}}\right)$, respectively.

layer considered (i.e. $600-125=475 \mathrm{~m}$ ), and RR is the Redfield $\mathrm{C}: \mathrm{O}_{2}$ molar ratio $(125: 175)$.

\section{Results}

\section{1 ${ }^{234} \mathrm{Th} /{ }^{238} \mathrm{U}$ ratio profiles}

The full data set, including activities of total ${ }^{234} \mathrm{Th}$ and ${ }^{238} \mathrm{U}$, and corresponding ${ }^{234} \mathrm{Th} /{ }^{238} \mathrm{U}$ ratios can be found in Supplement 1. Figure 2 shows depth profiles of total ${ }^{234} \mathrm{Th} /{ }^{238} \mathrm{U}$ ratios in the upper $1000 \mathrm{~m}$. The latitudinal section of ${ }^{234} \mathrm{Th} /{ }^{238} \mathrm{U}$ ratios is shown in Fig. 3a. From the Cape Basin to the northern Weddell Sea the surface waters appear clearly depleted in total ${ }^{234} \mathrm{Th}$ relative to its parent nuclide ${ }^{238} \mathrm{U}$. Lowest ${ }^{234} \mathrm{Th} /{ }^{238} \mathrm{U}$ ratios (average $0.77 \pm 0.04, n=11$ ) are found between the subtropical domain (station $\mathrm{S} 1,36.5^{\circ} \mathrm{S}$ ) and the northern PFZ (station L3, $44.9^{\circ} \mathrm{S}$ ). Southward in the PFZ, surface ${ }^{234} \mathrm{Th}$ deficits show a decrease with a mean
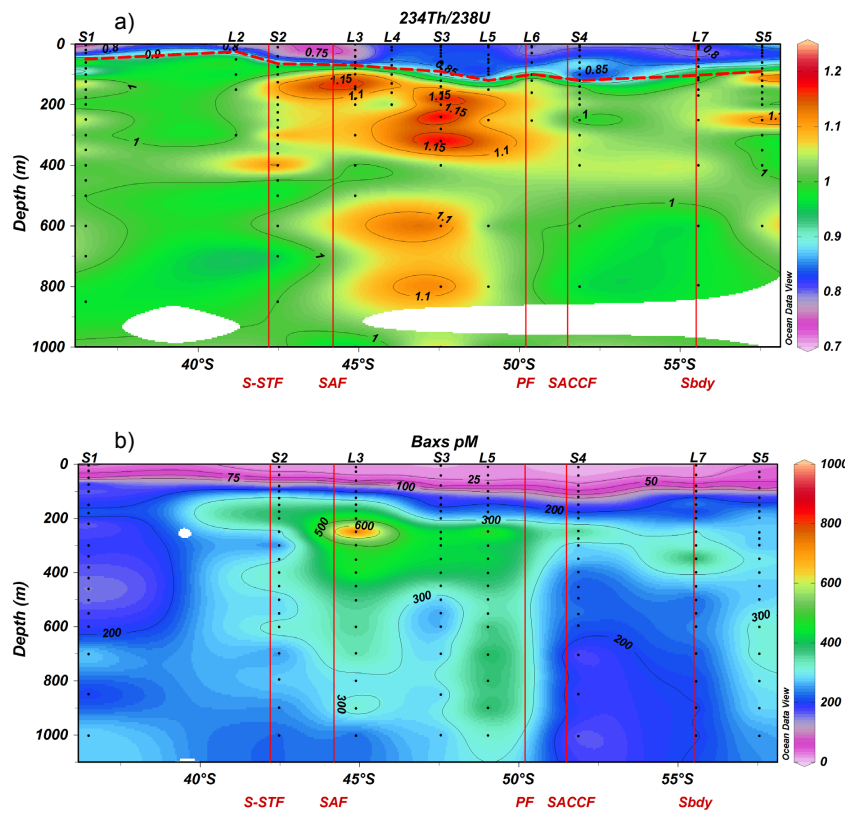

Fig. 3. Latitudinal section of (a) total ${ }^{234} \mathrm{Th} /{ }^{238} \mathrm{U}$ activity ratios and $(\mathbf{b})$ biogenic particulate $\mathrm{Ba}\left(\mathrm{Ba}_{\mathrm{xs}}\right)$ in the upper $1000 \mathrm{~m}$. Major frontal systems are indicated by vertical lines. The red dotted line indicates the mixed-layer depth (MLD). Schlitzer, 2003; Ocean Data View; http://www.awi-bremerhaven.de/GEO/ODV.

${ }^{234} \mathrm{Th} /{ }^{238} \mathrm{U}$ ratio of $0.84 \pm 0.04(n=23)$ and stay relatively unchanged until the northern Weddell Gyre (N-WG, station $\mathrm{S} 5,57.5^{\circ} \mathrm{S}$ ). This trend goes along with substantial deepening of the MLD which reaches $120 \mathrm{~m}$ at station L5 $\left(49.0^{\circ} \mathrm{S}\right)$ (Table 1).

Below the export layer ${ }^{234} \mathrm{Th}$ activity increases with depth and approaches equilibrium with ${ }^{238} \mathrm{U}$ at the bottom of the ML. At station S1, in the subtropical domain, it is observed that after reaching equilibrium at the base of the ML $(50 \mathrm{~m}$ depth) ${ }^{234} \mathrm{Th} /{ }^{238} \mathrm{U}$ ratio decreases again between 80 and $100 \mathrm{~m}$ depth (Fig. 2). A depletion of ${ }^{234} \mathrm{Th}$ indicates loss of ${ }^{234} \mathrm{Th}$ via particle scavenging and suggests a surface origin for this $30 \mathrm{~m}$ thick, less saline (salinity $=34.9$ ), subsurface water tongue. This may be related to the peculiar hydrography of this zone where cyclonic eddies can contribute to the subduction of surface waters of westward origin (Chever et al., 2010; Gladyshev et al., 2008). Deep total ${ }^{234}$ Th activities in the subtropical zone (S1 and L2) are close to secular equilibrium with ${ }^{238} \mathrm{U}$. However, substantial deep ${ }^{234} \mathrm{Th}$ excess is observed in the PFZ at $44.9^{\circ} \mathrm{S}$ (station L3), at $46.0^{\circ} \mathrm{S}$ (station L4) and at $47.5^{\circ} \mathrm{S}$ (station S3), and also to some extent at $42.5^{\circ} \mathrm{S}$ in the SAZ (station S2). ${ }^{234} \mathrm{Th} /{ }^{238} \mathrm{U}$ activity ratios largely $>1.1$ clearly indicate substantial accumulation of ${ }^{234} \mathrm{Th}$ (i.e. excess ${ }^{234} \mathrm{Th}$ relative to ${ }^{238} \mathrm{U}$ ) in the mesopelagic zone, which can be attributed to particle remineralisation and/or disaggregation (Buesseler et al., 2008; Maiti et al., 2010; Savoye et al., 2004a). Between the PF at $50.4^{\circ} \mathrm{S}$ (station L6) and the Sbdy at 55.2 ${ }^{\circ} \mathrm{S}$ (station L7) deep 
${ }^{234} \mathrm{Th}$ activity returns to secular equilibrium. However, further south, in the northern part of the Weddell Gyre at $57.6^{\circ} \mathrm{S}$ (station S5) we again observe layers of excess ${ }^{234} \mathrm{Th}$ activity (just below the ML and at $250 \mathrm{~m}$ depth; see Fig. 2).

\subsection{Export flux of ${ }^{234} \mathrm{Th}$}

\subsubsection{Surface export flux}

The fluxes of ${ }^{234} \mathrm{Th}$ out of the surface layer (upper $100 \mathrm{~m}$ and at MLD) were calculated using steady state (SS) and non steady state (NSS) models (Table 1 and Fig. 4a). The steady state model calculations reveal that ${ }^{234} \mathrm{Th}$ export at $100 \mathrm{~m}$ varies from $565 \mathrm{dpm} \mathrm{m}^{-2} \mathrm{~d}^{-1}$ at $41.2^{\circ} \mathrm{S}$ (station L2, STZ) to $1195 \mathrm{dpm} \mathrm{m}^{-2} \mathrm{~d}^{-1}$ at $50.4^{\circ} \mathrm{S}$ (station L6, PF). When integrating the ${ }^{234} \mathrm{Th}$ flux over the depth of the ML, the SS export flux of ${ }^{234} \mathrm{Th}$ ranges from 388 to $1521 \mathrm{dpm} \mathrm{m}^{-2} \mathrm{~d}^{-1}$ and compares relatively well with the fluxes at $100 \mathrm{~m}$. Differences arise for the stations located between $48^{\circ} \mathrm{S}$ and $55.2^{\circ} \mathrm{S}$ (PFZ to SACCF) where an important thickening of the ML $(>100 \mathrm{~m})$ is observed. At stations L5 $\left(49.0^{\circ} \mathrm{S}\right)$ and $\mathrm{S} 4\left(51.9^{\circ} \mathrm{S}\right)$ the $\mathrm{SS}^{234} \mathrm{Th}$ export flux from the upper $100 \mathrm{~m}$ is about $30 \%$ smaller than the flux from the ML. The SS export flux exhibits a latitudinal gradient which follows the structure of the upper ML (Fig. 4a). The smallest SS fluxes are observed in the STZ (stations S1 and L2), and also south of the ACC in the northern branch of the Weddell Gyre (station S5) where the ML is relatively shallow. ${ }^{234}$ Th export is highest within the ACC, especially in its southern part between the PFZ to the AZ (stations S3 to L7) where the upper ML extends quite deep ( 80 to $120 \mathrm{~m}$ ).

We also applied a non steady state (NSS) model to evaluate the ${ }^{234} \mathrm{Th}$ export flux by making use of total ${ }^{234} \mathrm{Th}$ activity data that were obtained during cruise ANTXXIV/3, (R/V Polarstern), also along the Greenwich Meridian and which preceded the BHG cruise by 2 to 3 weeks (Rutgers van der Loeff et al., 2011). NSS ${ }^{234}$ Th fluxes from the upper $100 \mathrm{~m}$ (Fig. 4a) range from $149 \mathrm{dpm} \mathrm{m}^{-2} \mathrm{~d}^{-1}$ at $41.2^{\circ} \mathrm{S}$ (station S2, STZ) to $1217 \mathrm{dpm} \mathrm{m}^{-2} \mathrm{~d}^{-1}$ at $55.2^{\circ} \mathrm{S}$ (station L7, AZ) and differ from the SS export fluxes (Table 2 and Fig. 4a). From the SAZ to the SACCF, the NSS ${ }^{234}$ Th flux is significantly lower than the SS flux and represents only between $15 \%$ (station S2, 42.5 $\mathrm{S}$ ) and $54 \%$ (station $\mathrm{L} 3,44.9^{\circ} \mathrm{S}$ ) of the latter. Such a difference indicates that surface export production was not at steady state over the time period separating the site occupations ( 15 to 21 days), which may be due to variable total ${ }^{234} \mathrm{Th}$ activity. In this case, lower NSS fluxes support an increase of the total ${ }^{234} \mathrm{Th}$ activity in the surface ML due to larger contribution of ${ }^{234} \mathrm{Th}$ in-growth from ${ }^{238} \mathrm{U}$. To the south, at $55.2^{\circ} \mathrm{S}$ (stations L7, AZ) and at $57.6^{\circ} \mathrm{S}$ (station S5, WG), the situation is different and the ${ }^{234} \mathrm{Th}$ fluxes evaluated using SS or NSS models show excellent agreement suggesting that surface ${ }^{234} \mathrm{Th}$ export has remained relatively constant over the period separating the two cruises.
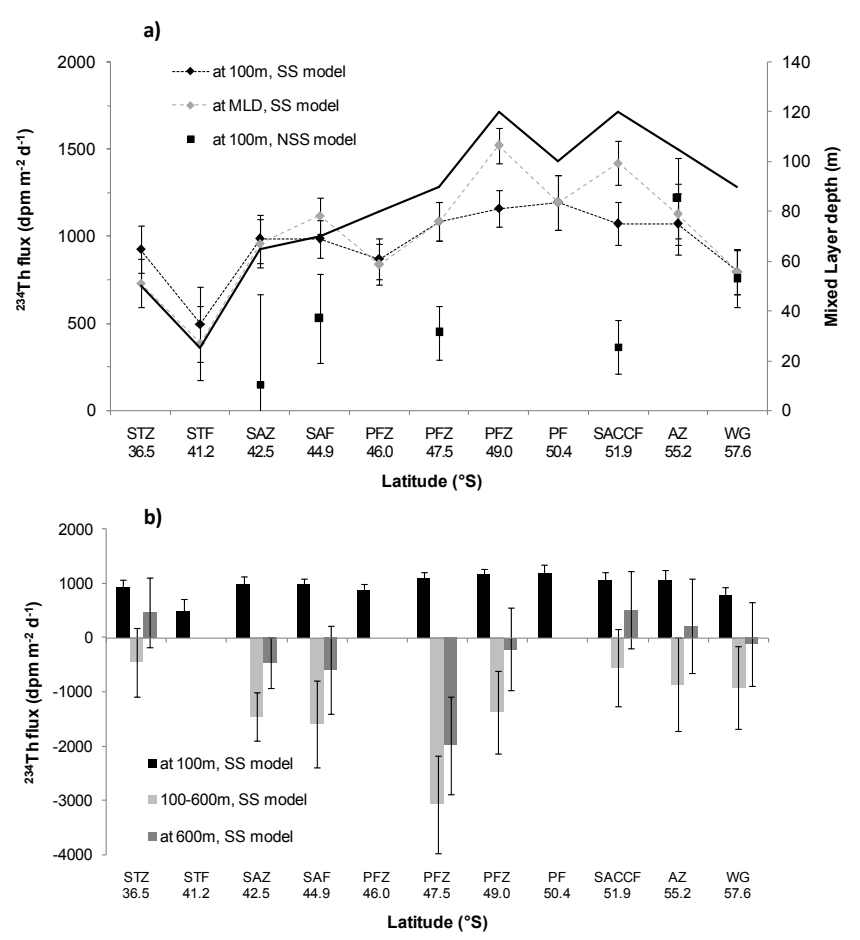

Fig. 4. (a) ${ }^{234} \mathrm{Th}$ export ( $\mathrm{dpm} \mathrm{m} \mathrm{m}^{-2} \mathrm{~d}^{-1}$ ) at $100 \mathrm{~m}$ (black diamonds) and at the base of the mixed layer (grey diamonds), calculated using the steady state model; black squares indicate ${ }^{234} \mathrm{Th}$ export at $100 \mathrm{~m}$ calculated using the non steady state model; (thick black line $=$ bottom of the mixed layer). (b) ${ }^{234} \mathrm{Th}$ fluxes $\left(\mathrm{dpm} \mathrm{m}^{-2} \mathrm{~d}^{-1}\right)$ at $100 \mathrm{~m}$; between 100 and $600 \mathrm{~m}$ and at $600 \mathrm{~m}$ calculated using the steady state model.

\subsubsection{Mesopelagic ${ }^{234} \mathrm{Th}$ fluxes}

Export fluxes of ${ }^{234} \mathrm{Th}$ at $600 \mathrm{~m}$ (called mesopelagic export flux here) are estimated for 8 stations for which upper $1000 \mathrm{~m}$ profiles of total ${ }^{234} \mathrm{Th}$ activities are available. These deep ${ }^{234} \mathrm{Th}$ fluxes were calculated using the SS model since no initial ${ }^{234} \mathrm{Th}$ values are available for the mesopelagic zone, and are reported as negative values in Fig. 4b. Negative fluxes of ${ }^{234} \mathrm{Th}$ (i.e., ${ }^{234} \mathrm{Th}$ excess over ${ }^{238} \mathrm{U}$ ) for the $100-600 \mathrm{~m}$ depth interval correspond to a net accumulation of ${ }^{234} \mathrm{Th}$ and probably reflect the remineralisation or disaggregation of ${ }^{234} \mathrm{Th}$-bearing particles within the mesopelagic layer. As illustrated in Fig. $4 \mathrm{~b}$ the mesopelagic accumulation of ${ }^{234} \mathrm{Th}$ varies largely with latitude, ranging from $458 \pm 633 \mathrm{dpm} \mathrm{m}^{-2} \mathrm{~d}^{-1}$ at $36.5^{\circ} \mathrm{S}$ (station S1, STZ) to $3068 \pm 897 \mathrm{dpm} \mathrm{m}^{-2} \mathrm{~d}^{-1}$ at $47.5^{\circ} \mathrm{S}$ (station $\mathrm{S} 3$, PFZ). It is strongest in the PFZ and the SAZ (1368 \pm 759 to $3068 \pm 897 \mathrm{dpm} \mathrm{m}^{-2} \mathrm{~d}^{-1}$ ) and largely exceeds SS ${ }^{234} \mathrm{Th}$ export from the upper $100 \mathrm{~m}$ resulting in negative total export fluxes from the upper $600 \mathrm{~m}$. Smaller ${ }^{234} \mathrm{Th}$ accumulation rates $\left(554 \pm 705\right.$ to $\left.921 \pm 756 \mathrm{dpm} \mathrm{m}^{-2} \mathrm{~d}^{-1}\right)$ are observed in the southern part of the BGH section. South of the PF, between $51.9^{\circ} \mathrm{S}\left(\mathrm{S} 4\right.$; SACCF) and $57.6^{\circ} \mathrm{S}(\mathrm{S} 5$; WG), the 
Table 2. Summary of the power law parameters for the vertical POC and particulate ${ }^{234} \mathrm{Th}$ activity profiles for $>53 \mu \mathrm{m}$ particles at Super stations S1 to S5. The used fitting function is $y=\mathrm{a} Z^{-\mathrm{b}}$, where $y=\mathrm{POC}$ concentrations in $\mu \mathrm{mol} \mathrm{L}-1$ and ${ }^{234} \mathrm{Th}_{\mathrm{p}}$ activity in dpm L $\mathrm{L}^{-b}$ and $Z=$ depth. Also listed are fitted values of POC concentration and ${ }^{234} \mathrm{Th}_{\mathrm{p}}$ activity at $100 \mathrm{~m}$ for $>53 \mu \mathrm{m}$ particles and estimated $\mathrm{POC}^{234} \mathrm{Th}_{\mathrm{p}}$ ratio $\left(\mu \mathrm{mol} \mathrm{dpm}^{-1}\right)$. These are compared with $\mathrm{POC} / 234 \mathrm{Th}_{\mathrm{p}}$ ratios obtained from averaging approach (see text for details).

\begin{tabular}{|c|c|c|c|c|c|c|c|c|c|c|c|c|}
\hline \multirow[t]{2}{*}{ Station } & \multirow[t]{2}{*}{ Zone } & \multirow{2}{*}{$\begin{array}{c}\text { depth range } \\
\text { (m) }\end{array}$} & \multicolumn{3}{|c|}{${ }^{234} \mathrm{Th}_{\mathrm{p}}$} & \multicolumn{3}{|c|}{ POC } & \multirow{2}{*}{$\frac{\text { Fitted }{ }^{234} \mathrm{Th}_{\mathrm{p}}}{\text { (at } 100 \mathrm{~m} \text { ) }}$} & \multirow{2}{*}{$\begin{array}{c}\text { Fitted POC } \\
\text { (at } 100 \mathrm{~m} \text { ) }\end{array}$} & \multicolumn{2}{|c|}{$\mathrm{POC}^{234} \mathrm{Th}_{\mathrm{p}}$} \\
\hline & & & $a$ & $b$ & $r^{2}$ & $a$ & $b$ & $r^{2}$ & & & $\begin{array}{c}\text { Fitted } \\
\text { (at } 100 \mathrm{~m})\end{array}$ & $\begin{array}{c}\text { Averaged } \\
(100-300 \mathrm{~m})\end{array}$ \\
\hline S1 & STZ & $50-2750$ & 0.32 & 0.66 & 0.834 & 1.93 & 0.88 & 0.868 & 0.015 & 0.034 & 2.2 & $1.9 \pm 0.2$ \\
\hline S2 & SAZ & $30-1460$ & 5.23 & 1.10 & 0.878 & 8.03 & 1.04 & 0.833 & 0.033 & 0.067 & 2.0 & $1.7 \pm 0.2$ \\
\hline S3 & PFZ & $20-2040$ & 0.90 & 0.81 & 0.869 & 1.95 & 0.77 & 0.835 & 0.021 & 0.056 & 2.6 & $3.0 \pm 0.2$ \\
\hline S4 & SACCF & $80-2468$ & 2.99 & 1.08 & 0.927 & 28.71 & 1.19 & 0.909 & 0.021 & 0.120 & 5.8 & $4.8 \pm 1.9$ \\
\hline S5 & WG & $50-3894$ & 3.75 & 1.08 & 0.775 & 27.56 & 1.19 & 0.824 & 0.026 & 0.115 & 4.4 & $4.1 \pm 1.7$ \\
\hline
\end{tabular}

mesopelagic accumulation of excess ${ }^{234} \mathrm{Th}$ is of similar magnitude, or smaller than the SS surface ${ }^{234}$ Th export flux, but it consistently decreases (S4, SACCF, and L7, AZ) or balances (S5) the total export flux of ${ }^{234} \mathrm{Th}$ at $600 \mathrm{~m}$.

\subsection{Particulate ${ }^{234}$ Th and POC}

Particulate ${ }^{234} \mathrm{Th}$ activities $\left({ }^{234} \mathrm{Th}_{p}\right)$ and POC concentrations for total suspended material (SPM) and for the two particle size classes ( $>53 \mu \mathrm{m}$ and $1-53 \mu \mathrm{m})$ at Super stations can be found in Supplement 2. High POC concentrations and ${ }^{234} \mathrm{Th}_{\mathrm{p}}$ activities are observed in the upper mixed layer but decrease rapidly in the subsurface waters and remain essentially constant below $200 \mathrm{~m}$. Surface POC and ${ }^{234} \mathrm{Th}_{\mathrm{p}}$ activity of total SPM range from 0.46 to $3.60\left(\mu \mathrm{mol} \mathrm{L}^{-1}\right)$ and from 0.28 to $0.99\left(\mathrm{dpm} \mathrm{L}^{-1}\right)$, respectively. Highest total POC concentrations and ${ }^{234} \mathrm{Th}_{\mathrm{p}}$ activities are observed in the SAZ (S2; $\left.42.5^{\circ} \mathrm{S}\right)$ and in the PFZ (S3; 47.5 $\left.\mathrm{S}\right)$. Lowest total POC and ${ }^{234} \mathrm{Th}_{\mathrm{p}}$ values are encountered in the surface waters of the STZ $\left(\mathrm{S} 1 ; 36.5^{\circ} \mathrm{S}\right)$ and the northern WG $\left(\mathrm{S} 5 ; 57.6^{\circ} \mathrm{S}\right)$. From STZ (S1) to SACCF (S4), the $1-53 \mu \mathrm{m}$ size fraction represents between 85 to $93 \%$ of total POC and from 84 to $96 \%$ of total ${ }^{234} \mathrm{Th}_{\mathrm{p}}$. This situation changes south of the Sbdy (S5, $57.6^{\circ} \mathrm{S}$ ) where $26 \%$ of total POC and $37 \%$ of total ${ }^{234} \mathrm{Th}_{\mathrm{p}}$ activity appears associated with large $(>53 \mu \mathrm{m})$ particles.

\subsection{POC to ${ }^{234} \mathrm{Th}$ ratios on particles}

Profiles of $\mathrm{POC} /{ }^{234} \mathrm{Th}_{\mathrm{p}}$ ratios for the two particle sizefractions are plotted in Fig. 5. Measured $\mathrm{POC} /{ }^{234} \mathrm{Th}_{\mathrm{p}}$ ratios vary from 0.7 to $6.8 \mu \mathrm{mol} \mathrm{dpm}^{-1}$ and from 0.8 to $16.3 \mu \mathrm{mol} \mathrm{dpm}^{-1}$ in small $(1-53 \mu \mathrm{m})$ and large $(>53 \mu \mathrm{m})$ particles, respectively. For most stations the mixed layer $\mathrm{POC} / 234 \mathrm{Th}$ ratios of the particles sizing $1-53 \mu \mathrm{m}$ are larger (S2, S3, S5) or similar (S1) compared with those for large $(>53 \mu \mathrm{m})$ particles. This is not the case at $\mathrm{S} 4\left(51.9^{\circ} \mathrm{S}\right.$; SACCF) where surface $\mathrm{POC} /{ }^{234} \mathrm{Th}_{\mathrm{p}}$ ratios for $>53 \mu \mathrm{m}$ particles are about twice as large as for the $1-53 \mu \mathrm{m}$ particles. Below the upper ML, POC/ ${ }^{234} \mathrm{Th}_{\mathrm{p}}$ ratios of small (1-53 $\left.\mu \mathrm{m}\right)$ particles in all cases decrease with depth to reach relatively constant values in the mesopelagic zone. For large (> 53 $\mu \mathrm{m})$ particles, $\mathrm{POC} /{ }^{234} \mathrm{Th}_{\mathrm{p}}$ ratios are much more variable (Fig. 5), decreasing at $\mathrm{S} 1$ and $\mathrm{S} 4$ but remaining unchanged at $\mathrm{S} 3$ and increasing at S2. At $\mathrm{S} 3$ between 400 and $500 \mathrm{~m}$ the very large values ( 14.1 to $16.3 \mu \mathrm{mol} \mathrm{dpm}^{-1}$ ) for the $>53 \mu \mathrm{m}$ particles are likely due to zooplankton collected on the filter (revealed from visual inspection). Zooplankton should have been removed prior to ${ }^{234} \mathrm{Th}$ and POC analysis since they are not part of the sinking particle flux.

For estimating POC export fluxes, the $\mathrm{POC} /{ }^{234} \mathrm{Th}_{\mathrm{p}}$ ratio of sinking particles at the export depth has to be determined (Buesseler et al., 1992). As recommended by Buesseler et al. (2006), we consider that the $\mathrm{POC} / 234 \mathrm{Th}_{\mathrm{p}}$ ratios of large $(>53 \mu \mathrm{m})$ particles are representative of sinking material leaving the upper ML. We considered the average $\mathrm{POC} /{ }^{234} \mathrm{Th}_{\mathrm{p}}$ ratio between the basis of the ML and $300 \mathrm{~m}$. $\mathrm{POC} /{ }^{234} \mathrm{Th}_{\mathrm{p}}$ ratios are smallest in the STZ and the SAZ and gradually increase southward from SAF to N-WG (Fig. 6). A southward increase of sinking particle $\mathrm{POC} /{ }^{234} \mathrm{Th}_{\mathrm{p}}$ ratios was also observed for particles sizing $>70 \mu \mathrm{m}$ in the Pacific sector between the SAZ and the Ross Sea (Buesseler et al., 2001), as well as across Drake Passage for $>50 \mu \mathrm{m}$ particles (Rutgers van der Loeff et al., 2011). To check the robustness of our averaging approach for evaluating $\mathrm{POC} /{ }^{234} \mathrm{Th}$ ratios of sinking particles we also fitted power law functions (Martin et al., 1987) to the vertical profiles of POC and ${ }^{234} \mathrm{Th}_{\mathrm{p}}$ of the $>53 \mu \mathrm{m}$ particle size fraction (Table 2) as also done by Jacquet et al. (2011). The vertical profiles of POC and ${ }^{234} \mathrm{Th}_{\mathrm{p}}$ fit rather well to a power law function $\left(R^{2}\right.$ ranging from 0.83 to 0.92 for both $>0.53 \mu \mathrm{m}$ POC and ${ }^{234} \mathrm{Th}_{p}$ ). Fitted values for POC and ${ }^{234} \mathrm{Th}_{\mathrm{p}}$ at $100 \mathrm{~m}$ depth are then used to deduce the $\mathrm{POC} /{ }^{234} \mathrm{Th}_{\mathrm{p}}$ ratio at $100 \mathrm{~m}$ (Table 2). Fitted $\mathrm{POC} /{ }^{234} \mathrm{Th}$ ratios at $100 \mathrm{~m}$ are very similar to the averages of $\mathrm{POC} /{ }^{234} \mathrm{Th}_{\mathrm{p}}$ ratios of between ML and $300 \mathrm{~m}$ (Fig. 6 and Table 2).

Overall, our POC ${ }^{234} \mathrm{Th}_{\mathrm{p}}$ ratios of sinking particles (Fig. 6) are of similar magnitude as those reported by others for the ACC, but regional differences exist. For instance, $\mathrm{POC} /{ }^{234} \mathrm{Th}_{\mathrm{p}}$ ratios of $>53 \mu \mathrm{m}$ particles in the PFZ (S3) 

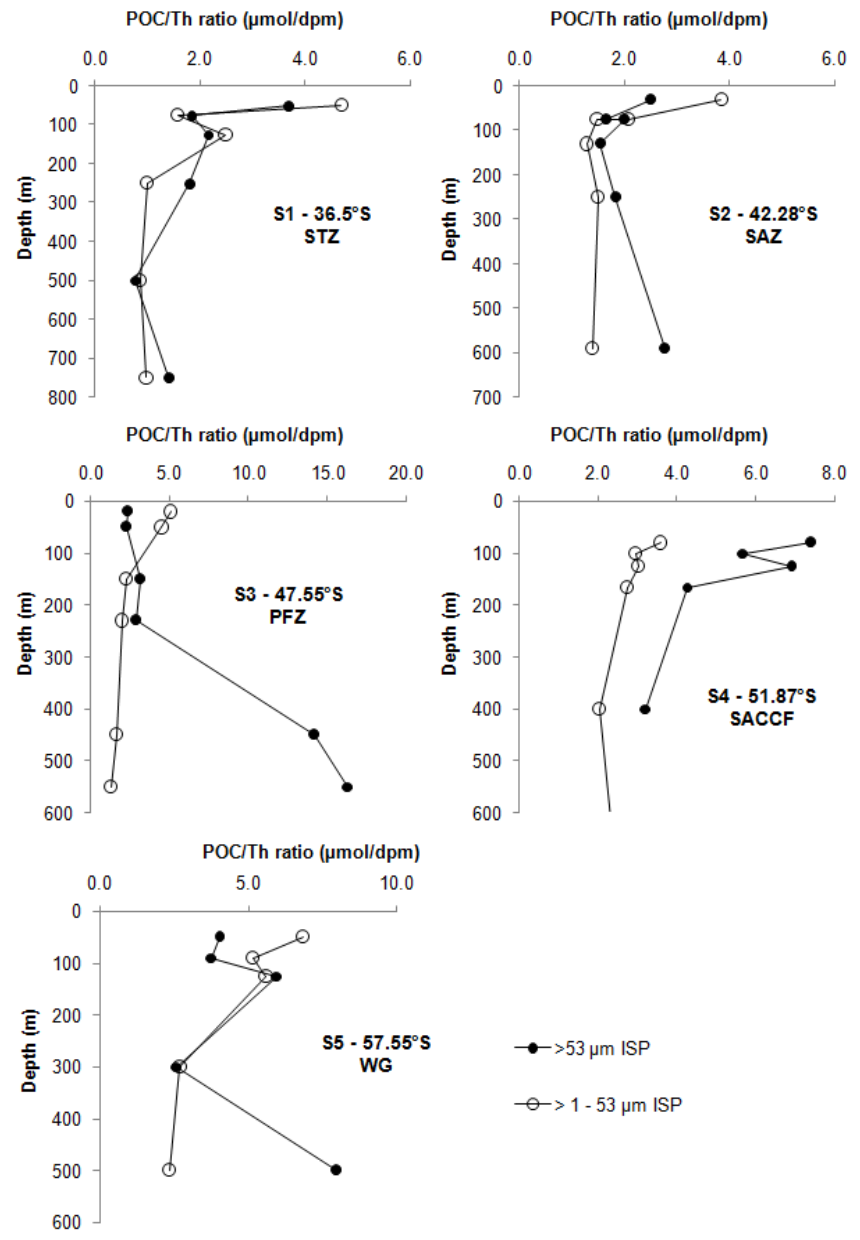

Fig. 5. Vertical profiles of $\mathrm{POC} /{ }^{234} \mathrm{Th}_{\mathrm{p}}$ ratio $\left(\mu \mathrm{mol} \mathrm{dpm}{ }^{-1}\right)$ for the $1-53 \mu \mathrm{m}$ and $>53 \mu \mathrm{m}$ size fractions at Super stations S1 to S5. ISP refers to In Situ Pump sampling.

and the WG (S5) are 1.5 to 1.8 times larger than those reported for the same locations 18 to 22 days earlier (Rutgers van der Loeff et al., 2011). Our range of $\mathrm{POC} / 234 \mathrm{Th}_{\mathrm{p}}$ ratios for the $>53 \mu \mathrm{m}$ fraction $\left(1.7 \pm 0.2\right.$ to $\left.4.8 \pm 1.9 \mu \mathrm{mol} \mathrm{dpm}^{-1}\right)$ is larger than the one reported by Coppola et al. (2005) for the Indian sector of the ACC $\left(0.8-1.4 \mu \mathrm{mol} \mathrm{dpm}^{-1}\right)$, but smaller than the range observed during bloom conditions, in natural iron-fertilized settings, close to Crozet Island (5.5-10.8 $\mathrm{mol} \mathrm{dpm}^{-1}$; Morris et al., 2007) and Kerguelen Island (5.9-11 $\mathrm{mol} \mathrm{dpm}^{-1}$; Savoye et al., 2008). Our POC/ $/{ }^{234} \mathrm{Th}_{\mathrm{p}}$ ratios for $>53 \mu \mathrm{m}$ particles in the SAZ $\left(1.74 \pm 0.21 \mu \mathrm{mol} \mathrm{dpm}^{-1}\right)$ are similar to values reported by Jacquet et al. (2011) for the eastern SAZ south of Tasmania $\left(2.06 \pm 0.30 \mu \mathrm{mol} \mathrm{dpm}^{-1}\right.$ at $\left.100 \mathrm{~m}\right)$, but smaller than for the western SAZ $\left(3.93 \pm 0.77 \mu \mathrm{mol} \mathrm{dpm}^{-1}\right.$ at $\left.100 \mathrm{~m}\right)$. For the PFZ our POC/234 $\mathrm{Th}_{\mathrm{p}}$ ratios $\left(3.01 \pm 0.21 \mu \mathrm{mol} \mathrm{dpm}^{-1}\right)$ are smaller than the one reported by Jacquet et al. (2011) for the PFZ south of Tasmania $\left(5.13 \pm 0.83 \mu \mathrm{mol} \mathrm{dpm}^{-1}\right.$ at $\left.100 \mathrm{~m}\right)$.

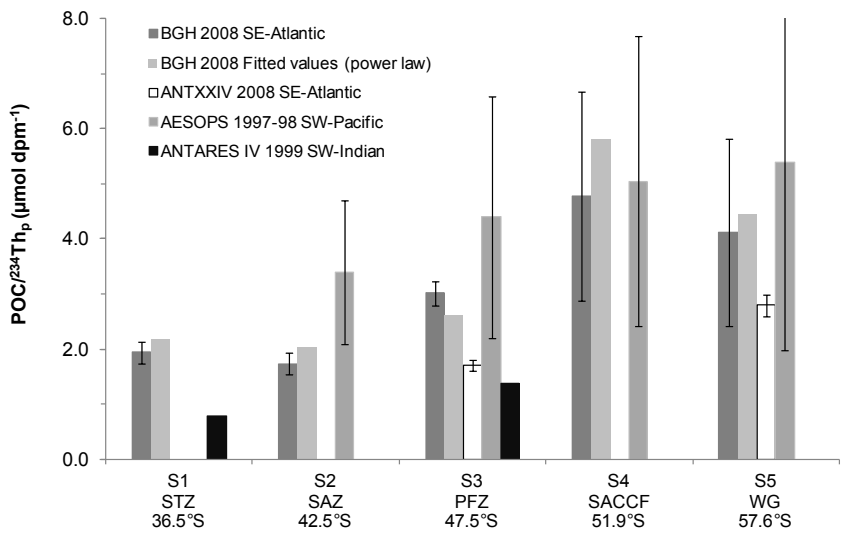

Fig. 6. Comparison of the $\mathrm{POC} /{ }^{234} \mathrm{Th}_{\mathrm{p}}$ ratio $\left(\mu \mathrm{mol} \mathrm{dpm}{ }^{-1}\right)$ of sinking particles $(>53 \mu \mathrm{m})$ at the five Super stations (S1 to S5) calculated using (i) average values of $\mathrm{POC} /{ }^{234} \mathrm{Th}_{\mathrm{p}}$ ratios between MLD and $300 \mathrm{~m}$ depth, and (ii) separate power law fits of the POC and ${ }^{234} \mathrm{Th}_{\mathrm{p}}$ profiles (see text for details). Also shown are $\mathrm{POC} /{ }^{234} \mathrm{Th}_{\mathrm{p}}$ ratios $\left(\mu \mathrm{mol} \mathrm{dpm}{ }^{-1}\right)$ reported for the ANTXXIV/3 cruise (Rutgers van der Loeff et al., 2011); the AESOPS cruise in the SW Pacific sector (Buesseler et al., 2001) and the ANTARES IV cruise in the Indian sector (Coppola et al., 2005).

We could not deploy large volume in situ pumps at all " $\mathrm{L}$ " stations. For L stations where no pumps were deployed and which were located close to a biogeochemical boundary (L2STF, L3-SAF, L6-PF, and L7-Sbdy), POC/234 $\mathrm{Th}_{\mathrm{p}}$ ratios were calculated by averaging the $\mathrm{POC} /{ }^{234} \mathrm{Th}_{\mathrm{p}}$ ratios measured in adjacent northern and southern zones (Table 3 ). For stations $\mathrm{L} 4$ and $\mathrm{L} 5$, located in the PFZ, we used the POC/ ${ }^{234} \mathrm{Th}_{\mathrm{p}}$ ratio obtained for S3 in the PFZ to calculate the POC flux.

\section{$3.5 \quad{ }^{234}$ Th-derived carbon flux}

\subsubsection{Surface export production}

The carbon export fluxes at $100 \mathrm{~m}\left(\mathrm{EP}_{100}\right)$ and at the MLD $\left(\mathrm{EP}_{\mathrm{ML}}\right)$ were estimated by multiplying the NSS or SS export fluxes of ${ }^{234} \mathrm{Th}\left(\mathrm{P}_{234 \mathrm{Th}}\right.$.) at $100 \mathrm{~m}$ and at MLD with the $\mathrm{POC} /{ }^{234} \mathrm{Th}_{\mathrm{p}}$ ratio of sinking particles. Overall, $\mathrm{EP}_{100}$ ranges from $0.9 \pm 0.4$ to $5.1 \pm 2.1 \mathrm{mmol} \mathrm{m}^{-2} \mathrm{~d}^{-1}$ and from $0.3 \pm 0.9$ to $4.9 \pm 3.3 \mathrm{mmol} \mathrm{m}^{-2} \mathrm{~d}^{-1}$ based on the SS and NSS model, respectively (Fig. 7a; Table 3). The SS EP 100 increases progressively from north to south. It remains low in the STZ and the SAZ but increases gradually from the PFZ to the N-WG. NSS EP 100 fluxes integrating the 15 to 22 day period preceding the $\mathrm{BGH}$ cruise, also exhibit a latitudinal gradient but the variability is larger compared to the SS approach (Fig. 7a). The highest NSS EP 100 fluxes are observed in the AZ, south of the ACC and in the WG with values now in close agreement with SS estimates. Within the ACC, from the SAZ to the SACCF, NSS EP ${ }_{100}$ fluxes range from $0.3 \pm 0.9$ to $1.7 \pm 1.0 \mathrm{mmol} \mathrm{m}^{-2} \mathrm{~d}^{-1}$ and represent only 15 to $53 \%$ of the SS export flux. 
Table 3. POC export production at $100 \mathrm{~m}\left(\mathrm{EP}_{100}\right)$ in $\mathrm{mmol} \mathrm{m}^{2} \mathrm{~d}^{-1}$ along the BGH section, as based on steady state (SS) and non steady state (NSS) models.

\begin{tabular}{|c|c|c|c|c|c|}
\hline \multirow[t]{2}{*}{ Station } & \multirow{2}{*}{$\begin{array}{l}\text { Lat } \\
{ }^{\circ} \mathrm{S}\end{array}$} & \multirow[t]{2}{*}{ Zone } & \multirow[t]{2}{*}{$\begin{array}{c}\mathrm{POC}^{234} \mathrm{Th} \\
\left(\mu \mathrm{mol} \mathrm{dpm}{ }^{-1}\right)\end{array}$} & \multicolumn{2}{|c|}{$\begin{array}{l}\text { C flux at } 100 \mathrm{~m} \\
\left(\mathrm{mmol} \mathrm{m}-2 \mathrm{~d}^{-1}\right)\end{array}$} \\
\hline & & & & SS model & NSS model \\
\hline S1 & 36.5 & STZ & $1.9 \pm 0.2$ & $1.8 \pm 0.3$ & \\
\hline L2 & 41.2 & STF & $1.8 \pm 0.3^{\mathrm{a}}$ & $0.9 \pm 0.4$ & \\
\hline S2 & 42.5 & SAZ & $1.7 \pm 0.2$ & $1.7 \pm 0.3$ & $0.3 \pm 0.9$ \\
\hline L3 & 44.9 & SAF & $2.4 \pm 0.7^{b}$ & $2.3 \pm 0.7$ & $1.3 \pm 0.7$ \\
\hline L4 & 46.0 & PFZ & - & $2.6 \pm 0.4^{\mathrm{e}}$ & \\
\hline $\mathrm{S} 3$ & 47.5 & PFZ & $3.0 \pm 0.2$ & $3.3 \pm 0.4$ & $1.3 \pm 0.5$ \\
\hline L5 & 49.0 & PFZ & - & $3.5 \pm 0.4^{\mathrm{e}}$ & \\
\hline L6 & 50.4 & $\mathrm{PF}$ & $3.9 \pm 2.1^{\mathrm{c}}$ & $4.7 \pm 2.6$ & \\
\hline S4 & 51.9 & $\mathrm{SACCF}$ & $4.8 \pm 1.9$ & $5.1 \pm 2.1$ & $1.7 \pm 1.0$ \\
\hline L7 & 55.2 & $\mathrm{AZ}$ & $4.0 \pm 2.6^{\mathrm{d}}$ & $4.3 \pm 2.8$ & $4.9 \pm 3.3$ \\
\hline S5 & 57.6 & WG & $4.1 \pm 1.7$ & $3.3 \pm 1.5$ & $3.1 \pm 1.5$ \\
\hline
\end{tabular}

${ }^{a}$ Mean of STZ (S1) and SAZ (S2) values; ${ }^{\mathrm{b}}$ mean of SAZ (S2) and PFZ (S3) values; ${ }^{\mathrm{c}}$ mean of PFZ (S3) and SACCF (S4) values; ${ }^{d}$ mean of SACCF (S4) and WG (S5) values; ${ }^{\mathrm{e}}$ calculated using PFZ (S3) POC/Th ratio.

Table 4. Remineralisation fluxes in mesopelagic waters, based on $\mathrm{Ba}_{\mathrm{xs}}$ contents and Eq. (2). Also listed are mesopelagic layer thickness, depth-weighted average mesopelagic $\mathrm{Ba}_{\mathrm{xs}}$ contents; calculated average $\mathrm{O}_{2}$ consumption rates $\left(\mu \mathrm{mol} \mathrm{L}{ }^{-1}\right)$ and column integrated respired $\mathrm{C}$ in $\mathrm{mmol} \mathrm{C} \mathrm{m}^{-2} \mathrm{~d}^{-1}$.

\begin{tabular}{|c|c|c|c|c|c|c|c|c|c|}
\hline \multirow[t]{2}{*}{ Station } & \multirow[t]{2}{*}{ Lat } & \multirow[t]{2}{*}{ Zone } & \multirow{2}{*}{$\begin{array}{c}\text { Cast } \\
\\
\\
\#\end{array}$} & \multicolumn{3}{|c|}{ Mesopelagic layer } & \multirow{2}{*}{$\frac{\text { meso-Ba }}{\mathrm{a} s}$} & \multirow{2}{*}{$\begin{array}{c}\mathrm{O}_{2} \\
\text { consumption } \\
\text { rate } J\left(\mathrm{O}_{2}\right)\end{array}$} & \multirow{2}{*}{ 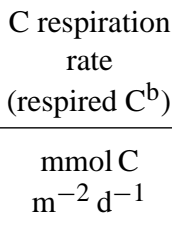 } \\
\hline & & & & $\begin{array}{l}\text { upper depth } \\
\text { m }\end{array}$ & $\begin{array}{l}\text { lower depth } \\
\text { m }\end{array}$ & $\begin{array}{c}\text { thickness } \\
\mathrm{m}\end{array}$ & & & \\
\hline S1 & $36.5^{\circ} \mathrm{S}$ & STZ & 23 & 125 & 600 & 475 & 168 & -0.0010 & -0.23 \\
\hline $\mathrm{S} 2$ & $42.5^{\circ} \mathrm{S}$ & SAZ & 24 & 125 & 600 & 475 & 284 & 0.0040 & 2.09 \\
\hline L3 & $44.9^{\circ} \mathrm{S}$ & SAF & 44 & 123 & 600 & 477 & 497 & 0.0175 & 6.39 \\
\hline S3 & $47.5^{\circ} \mathrm{S}$ & PFZ & 66 & 124 & 600 & 476 & 305 & 0.0075 & 2.50 \\
\hline L5 & $49.0^{\circ} \mathrm{S}$ & PFZ & 72 & 125 & 600 & 475 & 388 & 0.0041 & 4.16 \\
\hline S4 & $51.9^{\circ} \mathrm{S}$ & SACCF & 87 & 120 & 600 & 480 & 235 & 0.0049 & 1.11 \\
\hline L7 & $55.2^{\circ} \mathrm{S}$ & $\mathrm{AZ}$ & 99 & 125 & 600 & 475 & 277 & 0.0049 & 1.95 \\
\hline S5 & $57.6^{\circ} \mathrm{S}$ & WG & 110 & 123 & 600 & 477 & 271 & 0.0014 & 1.83 \\
\hline
\end{tabular}

a Meso-Baxs refers to the depth weighted average of Baxs content for the considered depth interval; ${ }^{\text {b }}$ Respired C is estimated from Eq. (2) (Dehairs et al., 1997).

Overall, the magnitude of the POC export flux from $100 \mathrm{~m}$ compares well with values obtained for the same transect a few weeks earlier (Rutgers van der Loeff et al., 2011). The best agreement is found when fluxes based on $\mathrm{POC} /{ }^{234} \mathrm{Th}_{\mathrm{p}}$ ratios for similar size fractions $(>53 \mu \mathrm{m}$ ) are compared (see PFZ, SACCF and WG locations in Fig. 7a). The matching between POC export fluxes based on total SPM POC/234 Th ratios (see SAZ, PFZ, SACCF, AZ and WG in Fig. 7a) is less clear though the latitudinal trend is similar. This discrepancy, apparently, mainly results from the fact that $\mathrm{POC} /{ }^{234} \mathrm{Th}_{\mathrm{p}}$ ratios for total SPM in the Rutgers van der Loeff et al. (2011) study exceed their ratios for large particles $(>53 \mu \mathrm{m})$ by a factor 1.4 to 1.9 .

\subsubsection{Mesopelagic carbon export flux}

In order to estimate the POC flux attenuation between 100 $600 \mathrm{~m}$ depth, we multiplied the accumulation fluxes of excess ${ }^{234} \mathrm{Th}$ in mesopelagic waters (steady state assumed) with the $\mathrm{POC} /{ }^{234} \mathrm{Th}_{\mathrm{p}}$ ratios of sinking particles. Attenuation of the POC flux is plotted as negative flux values in Fig. 7b. These range from $0.9 \pm 1.2 \mathrm{mmol} \mathrm{m}^{-2} \mathrm{~d}^{-1}$ (S1, STZ) to $9.2 \pm 2.9 \mathrm{mmol} \mathrm{m}^{-2} \mathrm{~d}^{-1}$ (S3, PFZ) and vary quite widely with latitude. Mesopelagic attenuation is lowest in the STZ, increases to $2.5 \pm 0.9 \mathrm{mmol} \mathrm{m}^{-2} \mathrm{~d}^{-1}$ to $2.8 \pm 2.2 \mathrm{mmol} \mathrm{m}^{-2} \mathrm{~d}^{-1}$ in the SAZ and reaches its maximum value in the central PFZ at $47.5^{\circ} \mathrm{S}$ (S3). Southward, values decrease progressively to $4.1 \pm 2.3 \mathrm{mmol} \mathrm{m}^{-2} \mathrm{~d}^{-1}$ in 

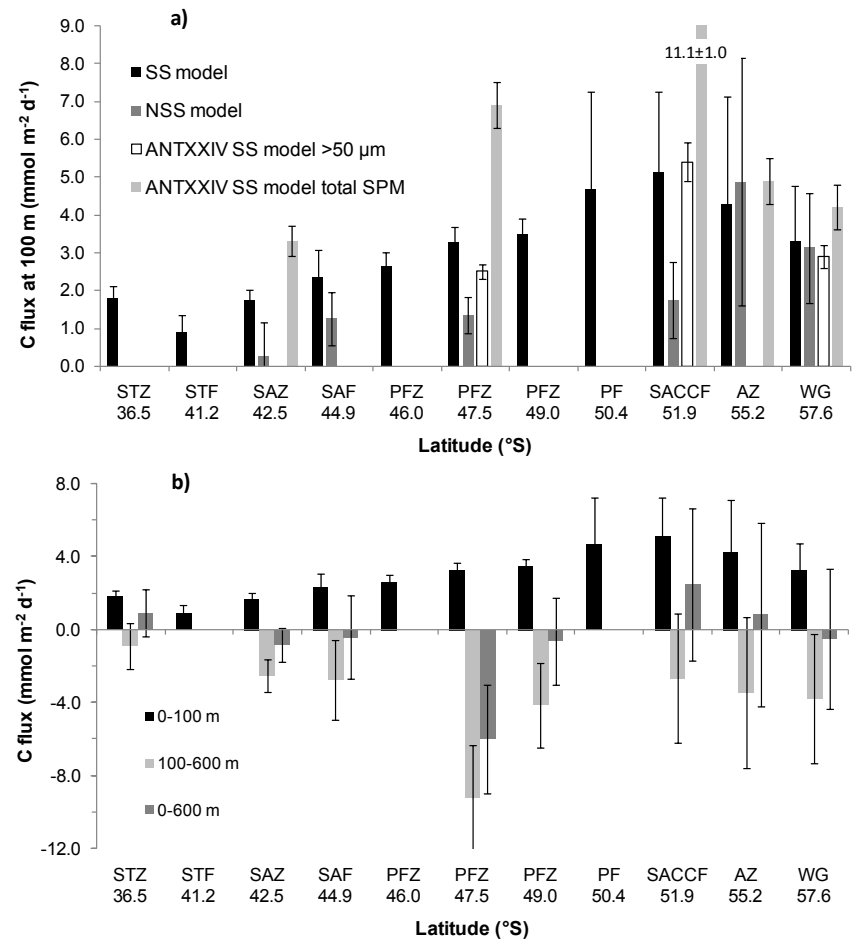

Fig. 7. (a) $100 \mathrm{~m}$-POC export fluxes $\left(\mathrm{mmol} \mathrm{m}^{-2} \mathrm{~d}^{-1}\right)$ estimated using SS and NSS models and comparison with export fluxes from $100 \mathrm{~m}$ for $>50 \mu \mathrm{m}$ particles and total suspended material reported for the ANTXXIV cruise (Rutgers van der Loeff et al., 2011). (b) Comparison of the POC export flux from the upper $100 \mathrm{~m}$; the POC flux between $100-600 \mathrm{~m}$ (deduced from the ${ }^{234}$ Th excess activity), and the total integrated POC export from the upper $600 \mathrm{~m}$ depth using the SS model.

the southern PFZ, to $2.6 \pm 3.6 \mathrm{mmol} \mathrm{m}^{-2} \mathrm{~d}^{-1}$ at the SACCF, and to $3.8 \pm 3.5 \mathrm{mmol} \mathrm{m}^{-2} \mathrm{~d}^{-1}$ in the northern WG.

This attenuation of the POC flux in mesopelagic waters leads to a significant decrease of the export from the upper $600 \mathrm{~m}\left(\mathrm{EP}_{600}\right)$. As illustrated in Fig. 7b, $\mathrm{EP}_{600}$ remains positive only for stations S1 (STZ), S4 (southern ACC) and L7 (AZ), where it represents between $20 \%$ (L7) and 50\% (S1 and S4) of $\mathrm{EP}_{100}$. At stations S2 (SAZ; $\left.42.5^{\circ} \mathrm{S}\right), \mathrm{L} 3$ (SAF; 44. $\left.9^{\circ} \mathrm{S}\right)$, L5 (PFZ; $49.0^{\circ} \mathrm{S}$ ) and S5 (WG; 57.6 ${ }^{\circ} \mathrm{S}$ ), surface export and mesopelagic attenuation of POC can be considered in balance within analytical uncertainties, thus indicating no deep POC export there. However, at S3 (PFZ; $47.5^{\circ} \mathrm{S}$ ) mesopelagic attenuation significantly exceeds surface POC export (2.8 times). Such imbalance suggests that the SS assumption can be invalid for modelling ${ }^{234}$ Th activity. Since at S3 NSS POC export is $<$ SS POC export, the excess of $\mathrm{EP}_{600}$ relative to $\mathrm{EP}_{100}$ would be even larger (Fig. 7a). A discrepancy between surface export and subsurface remineralisation is also reported by Savoye et al. (2004a) for the AZ and in the seasonal ice zone (SIZ) of the Australian sector. A possible explanation for such imbalance may be the decoupling of surface and mesopelagic processes due, for instance, to lat- eral advection of surface waters. The strong eastward surface current in the central ACC may have advected surface waters with lower ${ }^{234} \mathrm{Th}$ deficit and lower particle export relative to the signal captured at mesopelagic depth.

\subsection{Ba $_{x s}$ profiles}

While surface waters are depleted in $\mathrm{Ba}_{\mathrm{xs}}$, concentrations start to increase at the base of the MLD where the density gradient gets steeper (Figs. 2 and $3 b$, the full dataset can be found in Supplement 3). In the STZ and SAZ, the subsurface buildup of $\mathrm{Ba}_{\mathrm{xs}}$ starts at about $50 \mathrm{~m}$ but this depth progressively increases in the ACC $(\sim 100 \mathrm{~m})$ to shoal again slightly southward. This is consistent with previous observations and supports the view that aggregates formed at the basis of the mixed layer are loci where barite precipitates (Cardinal et al., 2005). The $\mathrm{Ba}_{\mathrm{xs}}$ contents are usually maximal in the 200 $400 \mathrm{~m}$ layer but high values exceeding $300 \mathrm{pM}$ can be found down to 600-800 m (L3, SAF; L5, PFZ; S5, WG). The highest value for the whole transect is reached at station L3 (SAF) at $250 \mathrm{~m}(>1000 \mathrm{pM})$. Such high values have already been reported on the SAF and SAZ (Jacquet et al., 2005). This $\mathrm{Ba}_{\mathrm{xs}}$ maximum is surrounded by values which remain high (>400 pM) over the 125-475 m depth range.

$\mathrm{Ba}_{\mathrm{xs}}$ contents are the lowest for the northernmost (STZSAZ) and the southernmost (SACCF-AZ-WG) parts of the BGH section. This spatial variability is also clearly expressed in the depth weighted average mesopelagic $\mathrm{Ba}_{\mathrm{xs}}$ (meso- $\mathrm{Ba}_{\mathrm{xs}}$ ) contents $\left(125-600 \mathrm{~m}\right.$; Table 4). Meso- $\mathrm{Ba}_{\mathrm{xs}}$ is minimal at $\mathrm{S} 1$ (STZ; $168 \mathrm{pM}$ ) and maximal at L3 (SAF; $497 \mathrm{pM}$ ). The two PFZ stations have meso- $\mathrm{Ba}_{\mathrm{xs}}$ contents exceeding $300 \mathrm{pM}$ while all other stations have moderate meso- $\mathrm{Ba}_{\mathrm{xs}}$ contents (235-277 pM). Such a trend with maximum meso-Ba $a_{\mathrm{xs}}$ values around the PFZ and lower values northward and southward has been observed earlier (Cardinal et al., 2005; Jacquet et al., 2011).

\section{Discussion}

\subsection{From ${ }^{234}$ Th activity to POC export fluxes}

\subsubsection{Neglecting the physics}

We have assumed when applying the SS and NSS models that supply and loss of ${ }^{234} \mathrm{Th}$ via physical transport was negligible relative to production and decay of ${ }^{234} \mathrm{Th}$ and loss via settling particles. This assumption is often justified in open ocean settings because of minimal advection and diffusion and small gradients in ${ }^{234} \mathrm{Th}$ activities (Savoye et al., 2006). As the oceanic domain south of South Africa is a region of intense mesoscale activity (Arhan et al, 2011), horizontal advection and diffusion may be significant there. Gladyshev et al. (2008) and Chever et al. (2010) indeed report the occurrence of eddies detached from the Agulhas retroflection, advecting and subducting colder surface waters of westward 
origin. In case such waters would advect a larger ${ }^{234} \mathrm{Th}$ deficit, the observed ${ }^{234} \mathrm{Th}$ deficit between 80 and $100 \mathrm{~m}$ depth at STZ station S1, if taken to be of genuine local origin, would result in an overestimation of the true ${ }^{234} \mathrm{Th}$ and POC fluxes. Therefore the flux values for site S1 need to be considered with caution. The Antarctic Zone is a region of net upwelling where vertical advection and diffusion supply deep waters, with their ${ }^{234} \mathrm{Th}$ in secular equilibrium with ${ }^{238} \mathrm{U}$, to the surface. With an entrainment rate of the order of $50 \mathrm{~m} \mathrm{yr}^{-1}$ (Rutgers van der Loeff et al., 2011), the ${ }^{234} \mathrm{Th}$ deficit in a $100 \mathrm{~m} \mathrm{SML}$ is flushed once every two years, yielding a ventilation rate that is an order of magnitude smaller than the ${ }^{234} \mathrm{Th}$ ingrowth rate of $10.5 \mathrm{yr}^{-1}$ (Rutgers van der Loeff et al., 2011). Therefore, such upwelling can reasonably be neglected when modelling the ${ }^{234}$ Th activity balance.

\subsubsection{Steady state vs. non steady state surface export production}

POC flux estimates based on SS and NSS models (Fig. 7a) may differ, depending on the considered biogeochemical province. From the SAZ to the SACCF the POC flux based on the NSS model is smaller than the SS fluxes, representing only between $17 \%\left(42.5^{\circ} \mathrm{S}\right.$, station $\left.\mathrm{S} 2\right)$ to $56 \%\left(44.9^{\circ} \mathrm{S}\right.$, station L3) of the latter. Based on the results of a high resolution model, Resplandy et al. (2012) conclude that the NSS approach can be biased in case spatial variability is misinterpreted as temporal variability. Flux results for high kinetic areas, in particular, would be prone to such bias. The question thus rises whether this mismatch between SS and NSS fluxes possibly results from the fact that different water masses were sampled during the two cruises. A careful comparison of sea surface height patterns (from altimetry) between the BGH and the ANTXXIV/3 cruises, however, revealed no significant change in eddy patterns for the particularly kinetic northern part of the studied area, over the time span of two weeks separating the 2 cruises (S. Speich, personal communication, 2012). This observation taken together with the fact that T-S diagrams for the station pairs considered in the NSS approach are similar, warrants the outcome of our NSS flux calculations.

Higher $\mathrm{EP}_{100}$ values obtained with the SS model $\left(1.7 \pm 0.3\right.$ to $\left.3.9 \pm 2.1 \mathrm{mmol} \mathrm{m}^{-} \mathrm{d}^{-1}\right)$ may indicate that a significant fraction of the export occurred earlier in the growth season. This finding is supported further by the ${ }^{234} \mathrm{Th}$ export fluxes (at $100 \mathrm{~m}$ ) from the ANTXXIV cruise (Rutgers van der Loeff et al., 2011). In the latter study, $100 \mathrm{~m}^{234} \mathrm{Th}$ export fluxes between $42^{\circ} \mathrm{S}$ and $53^{\circ} \mathrm{S}$ range from $1006 \pm 94$ to $1670 \pm 103 \mathrm{dpm} \mathrm{m}^{-} \mathrm{d}^{-1}$, and are similar $\left(42.5^{\circ} \mathrm{S}, \mathrm{S} 2\right)$ or as much as $69 \%$ higher $\left(44.9^{\circ} \mathrm{S}, \mathrm{L} 3\right)$ than our estimates. This may be related to the diatom spring bloom (December) revealed by monthly means of remotely sensed Chl $a$ distribution between $42^{\circ} \mathrm{S}$ to $50^{\circ} \mathrm{S}$ (Rutgers van der Loeff et al., 2011), in line with the silicate drawdown observed in the PFZ (Le Moigne et al, 2013).
For the southernmost stations L7 and S5, NSS and SS $\mathrm{EP}_{100}$ closely agree (NSS $\mathrm{EP}_{100} / \mathrm{SS} \quad \mathrm{EP}_{100}=1.14$ and 0.95 at $\mathrm{L} 7$ and $\mathrm{S} 5$, respectively) suggesting that POC export did occur under close to steady state conditions. This is confirmed by the good agreement between our SS ${ }^{234} \mathrm{Th}$ fluxes $\left(1072 \pm 175 \mathrm{dpm} \mathrm{m}^{-2} \mathrm{~d}^{-1}\right.$ at $55.2^{\circ} \mathrm{S}, \quad \mathrm{L} 7$ and $800 \pm 130 \mathrm{dpm} \mathrm{m}^{-2} \mathrm{~d}^{-1}$ at $57.6^{\circ} \mathrm{S}$, $\mathrm{S} 5, \mathrm{WG})$ and the fluxes reported for the same sites 22 days earlier $\left(1058 \pm 97 \mathrm{dpm} \mathrm{m}^{-2} \mathrm{~d}^{-1}\right.$ at $54.3^{\circ} \mathrm{S}$ and $848 \pm 106 \mathrm{dpm} \mathrm{m}^{-2} \mathrm{~d}^{-1}$ at $57.0^{\circ} \mathrm{S}$; Rutgers van der Loeff et al., 2011). This condition of significant phytoplankton production sustaining carbon export during late summer is corroborated by the observations of relatively high new production in the AZ and WG areas (Joubert et al., 2011). Significant phytoplankton activity also fits with a rapid drawdown of surface dissolved Fe (DFe) over 21 days, with $\mathrm{DFe}$ decreasing from $0.33 \mathrm{nM}$ at $55.0^{\circ} \mathrm{S}$ and $0.34 \mathrm{nM}$ at $56.0^{\circ} \mathrm{S}$ (ANTXXIV cruise; Klunder et al., 2011) to $<0.1 \mathrm{nM}$ at $55.2^{\circ} \mathrm{S}(\mathrm{L} 7)$ and $0.14 \mathrm{nM}$ at $57.6^{\circ} \mathrm{S}(\mathrm{S} 5)$ (the present $\mathrm{BGH}$ cruise; Chever et al., 2010).

\subsubsection{POC $/ 234 \mathrm{Th}_{\mathrm{p}}$ ratio of sinking particles}

The $\mathrm{POC} /{ }^{234} \mathrm{Th}_{\mathrm{p}}$ ratios of sinking particles $(>53 \mu \mathrm{m})$ increase with latitude (Fig. 6). Higher $\mathrm{POC}^{234} \mathrm{Th}_{\mathrm{p}}$ ratios may result from the presence of larger particles due to increasing particle volume to surface area ratios $(V: S A)$ (Buesseler et al., 2006). The occurrence of high $\mathrm{POC} /{ }^{234} \mathrm{Th}_{\mathrm{p}}$ ratios in the $\mathrm{SO}$ has been reported to be related to diatom blooms (Buesseler et al., 2001, 2003, 2007; Friedrich and Rutgers van der Loeff, 2002; Rutgers van der Loeff et al., 1997, 2002; Savoye et al., 2008). The higher values of $\mathrm{POC} /{ }^{234} \mathrm{Th}_{\mathrm{p}}$ ratios in the present study also coincide with the progressive increase of diatom abundance in silicate-rich $(>10 \mu \mathrm{M})$ surface waters south of the PF (Le Moigne et al., 2012). Lower POC/ ${ }^{234} \mathrm{Th}_{\mathrm{p}}$ ratios of sinking particles observed in the STZ (station S1), the SAZ (S2), and the northern PFZ (S3) (Fig. 6) on the contrary, appear associated with conditions of low silicate levels limiting diatom growth and presence of a mixed phytoplankton community of small sized cells (Bown et al., 2011; Fripiat et al., 2011).

A change in the $V: S A$ ratio is not the only factor that can alter the $\mathrm{POC} /{ }^{234} \mathrm{Th}_{\mathrm{p}}$ ratio of particles (Buesseler et al., 2006). As shown in Fig. 5, the surface water $\mathrm{POC}^{234} \mathrm{Th}_{\mathrm{p}}$ ratios of large and small particles exhibit large differences between sites. Higher POC/ ${ }^{234} \mathrm{Th}_{\mathrm{p}}$ ratios in the $>53 \mu \mathrm{m}$ size fraction are in fact observed only for station $\mathrm{S} 4$, while at other stations, surface ratios of large particles are similar to those of small particles $(1-53 \mu \mathrm{m})$ (see $\mathrm{S} 1$ ) or are even smaller (S2, S3, and S5), suggesting other controlling factors. Similar POC/ ${ }^{234} \mathrm{Th}_{\mathrm{p}}$ ratios for both particle size classes may be consistent with rapid aggregation of small particles into larger sinking ones, possibly reflecting the impact of TEPproducing phytoplankton species (Buesseler et al., 2006). On the other hand decreasing $\mathrm{POC} /{ }^{234} \mathrm{Th}_{\mathrm{p}}$ ratios with particle 


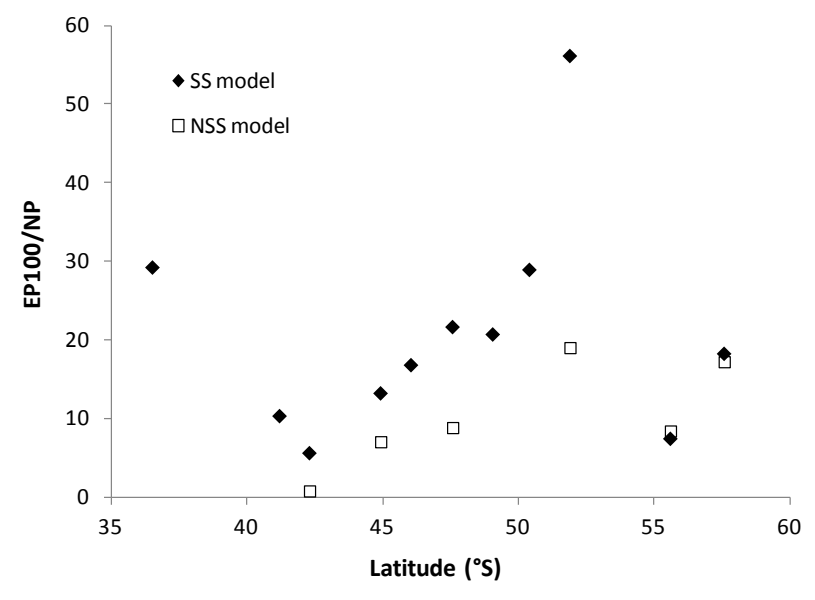

Fig. 8. Latitudinal variation of SS and NSS POC export flux at $100 \mathrm{~m}$ as a $\%$ of new production (NP; Joubert et al., 2011).

size may reflect preferential C loss relative to ${ }^{234} \mathrm{Th}$ during large particle generation. This may include $\mathrm{C}$ degradation and recycling in the surface as well as variable $\mathrm{C}$ assimilation rates between trophic levels, including production of fecal material by zooplankton (Buesseler et al., 2006).

\subsection{Surface fluxes}

Chlorophyll $a$, POC and PON measurements reveal that phytoplankton abundance was highest in the STZ (L2) and in the SAZ (S2), while southward algal biomass decreased progressively in the PFZ and reached minimum values between the SACCF and the Sbdy (Joubert et al., 2011). At "Super" stations the regression of surface POC and particulate ${ }^{234} \mathrm{Th}$ activity of total SPM (from in situ pump sampling) yields a correlation coefficient $\left(R^{2}\right)$ of $0.911(n=7)$. This relationship is preserved $\left(R^{2}=0.808, n=48\right)$ when considering full water column data. While particulate ${ }^{234} \mathrm{Th}$ thus appears to mirror plankton biomass, surface export production $\left(\mathrm{EP}_{100}\right.$ and $\mathrm{EP}_{\mathrm{ML}}$ ) does not display any such relationship. In the STZ and in the SAZ, POC export fluxes are minimal, whereas in the low $\mathrm{Chl} a$ and POC area at $\mathrm{S} 4$ in the $\mathrm{AZ}, \mathrm{EP}_{100}$ is highest (Fig. 7a).

Nitrogen uptake and new production (NP) estimates obtained during BGH (Joubert et al., 2011) might provide further insight into the processes controlling surface POC export. From Joubert et al. (2011) it appears that the late summer oligotrophic conditions in the STZ supported a phytoplanktonic community based on regenerated production, as evidenced by low f-ratios (0.2), and dominance of urea uptake (70\% of total $\mathrm{N}$ uptake). This regenerated-nutrient based community appeared dominated by small sized phytoplankton (51\% of the $\mathrm{Chl} a$ content was associated with picophytoplankton sizing $<2 \mu \mathrm{m}$; Joubert et al., 2011), what is consistent with the small POC export flux deduced from ${ }^{234} \mathrm{Th}\left(0.9-1.8 \mathrm{mmol} \mathrm{m}^{-2} \mathrm{~d}^{-1}\right)$. Further south, the decrease of regenerated production (Joubert et al., 2011) concurrent with a decreasing contribution of the smaller sized phytoplankton, parallels the trend of increasing $\mathrm{EP}_{100}$ (Fig. 7a). This is indirect further evidence that enhanced nutrient cycling by the microbial loop appears to lower surface POC export in the northern part of the section. Comparison between $\mathrm{EP}_{100}$ fluxes and urea uptake using a linear fitting function indicate a negative relationship (slope of -0.17 ), though the correlation is poor $\left(R^{2}=0.22, p=0.143, n=11\right)$, indicating other controlling factors are operating as well.

We note that POC export fluxes represent between 6 and $56 \%$ of new production (NP values from Joubert et al., 2011) for SS $\mathrm{EP}_{100}$ and between 1 and $19 \%$ of NP for NSS EP $\mathrm{EP}_{100}$ (Fig. 8). For stations L5 $\left(49.0^{\circ} \mathrm{S}\right)$ and $\mathrm{S} 4\left(51.9^{\circ} \mathrm{S}\right)$, where the MLD extends deeper (to $120 \mathrm{~m}$ ), the SS EP $\mathrm{ML}_{\mathrm{ML}}$ exceeds the $\mathrm{EP}_{100}$ and amounts to 24 and $68 \%$ of NP at L5 and S4, respectively. As discussed by Henson et al. (2011) and Joubert et al. (2011), reasons for such discrepancy between NP and EP include a possible overestimation of f-ratio because of nitrification in the euphotic layer, the export of dissolved organic carbon and the fact that uptake of other reduced $\mathrm{N}$ species, such amino acids, is usually not considered in the f-ratio approach. Also, differences in time and space scales covered by the NP and the ${ }^{234} \mathrm{Th}$ approaches can partly explain the observed discrepancies. Bearing in mind that NP represents the potential export of both dissolved and particulate material, the ratio of POC export from ${ }^{234} \mathrm{Th}$ over NP illustrates the POC export efficiency. Export efficiency appears particularly low for the SAZ (6\%), the PFZ (13 to $21 \%$ ), the AZ $(7 \%)$ and the N-WG (18\%), while it is larger at the PF $(29 \%)$ and at the SACCF (56\%). When considering the survey period covered by the NSS model (15 to 21 days), POC export efficiency is even lower and represents only between $1 \%$ (SAZ) to $19 \%$ (SACCF) of NP. Note that POC export, in principle, has to be gauged against net primary production (NPP) to obtain the true export ratio or the ratio defined by Buesseler (1998). Although C uptake rates were not measured during BGH (Joubert et al., 2011), the discrepancies between $\mathrm{EP}_{100}$ and NP do reflect that the biological C pump was rather inefficient in exporting $\mathrm{C}$ out of the euphotic zone during this late summer condition.

\subsection{Mesopelagic POC remineralisation}

The vertical distribution of excess ${ }^{234} \mathrm{Th}$ and $\mathrm{Ba}_{\mathrm{xs}}$ in mesopelagic waters (Fig. 2) show that the depth range where particle remineralisation/disaggregation is most intense strongly varies along the BGH section. In the STZ (S1) and the WG (S5), ${ }^{234} \mathrm{Th}$ accumulation is relatively shallow and peaks in the subsurface between 120 and $250 \mathrm{~m}$. Evidence of shallow remineralisation has also been reported for the NW Pacific (Maiti et al., 2010), the Sargasso Sea, as associated with mesoscale eddies (Buesseler et al., 2008), and in the SO during the SOFEX experiment (Buesseler et al., 2005). Between the SAZ (S2) and the SACCF (S4) the layer 

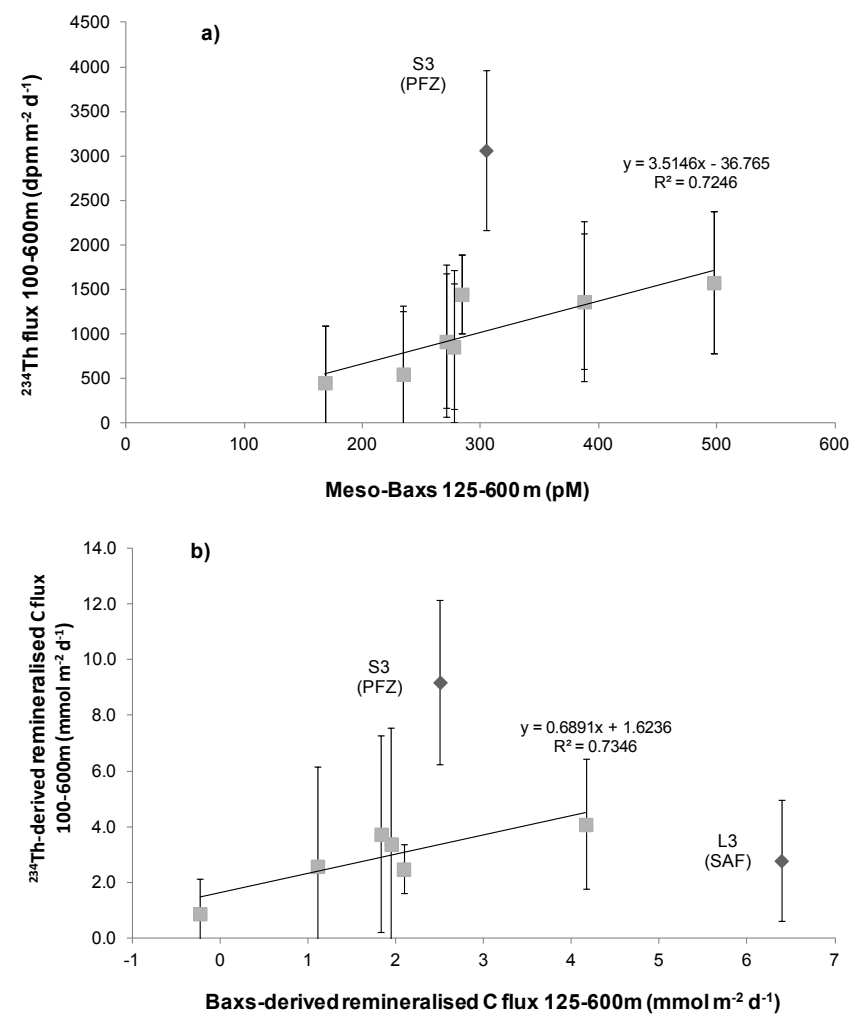

Fig. 9. (a) Depth-weighted average mesopelagic excess Ba (meso$\mathrm{Ba}_{\mathrm{xs}}$; pM, 125-600 $\mathrm{m}$ ) versus mesopelagic ${ }^{234} \mathrm{Th}$ accumulation flux (100-600 m); (b) $\mathrm{C}$ remineralisation flux deduced from $\mathrm{Ba}_{\mathrm{xs}}$ $\left(\mathrm{C}_{\text {respired }}\right.$ in mmol $\left.\mathrm{Cm}^{-2} \mathrm{~d}^{-1}\right)$ plotted versus $\mathrm{C}$ remineralisation flux (in mmol $\mathrm{Cm}^{-2} \mathrm{~d}^{-1}$ ) deduced from ${ }^{234} \mathrm{Th}$ excess activity in the mesopelagic layer $(100-600 \mathrm{~m})$ and the $\mathrm{POC} /{ }^{234} \mathrm{Th}_{\mathrm{p}}$ ratio $\left(\mu \mathrm{mol} \mathrm{dpm}{ }^{-1}\right)$ of $>53 \mu \mathrm{m}$ particles.

with excess ${ }^{234} \mathrm{Th}$ and high $\mathrm{Ba}_{\mathrm{xs}}$ is consistently broader. As shown in Fig. 2, ${ }^{234} \mathrm{Th}$ enrichments extend from below the upper mixed layer to $400 \mathrm{~m}$ in the SAZ (S2) and $1000 \mathrm{~m}$ in the SAF (L3). Such a thick layer of excess ${ }^{234}$ Th has also been reported for the central Weddell Gyre (Usbeck et al., 2002) and the SO Atlantic (Rutgers van der Loeff et al., 1997), and Australian sectors (Savoye et al., 2004a). Average concentrations of meso- $\mathrm{Ba}_{\mathrm{xs}}$ and excess Th flux are significantly correlated (Fig. 9a; $R^{2}=0.73 ; p=0.015$; one outlier, S3-PFZ excluded). This relationship is preserved $\left(R^{2}=\right.$ 0.69 ) when excess ${ }^{234}$ Th fluxes at L5, S4 are computed taking the MLD rather than $100 \mathrm{~m}$ as the upper boundary of the ${ }^{234} \mathrm{Th}$ excess layer. Likewise, $\mathrm{C}$ remineralisation fluxes based on $\mathrm{Ba}_{\mathrm{xs}}$ contents correlate well with excess ${ }^{234} \mathrm{Th}$ flux, except for two outliers (Fig. 9b). The latter are station L3 (SAF) which had the highest $\mathrm{Ba}_{\mathrm{xs}}$ based remineralisation flux and station S3 (PFZ) which had the highest excess ${ }^{234}$ Th based flux. Excluding these two sites yields a correlation coefficient $R^{2}=0.73\left(R^{2}=0.56\right.$ in case the MLD is taken as the upper boundary of the ${ }^{234} \mathrm{Th}$ excess layer). Note that remineralisation fluxes calculated based on $\mathrm{Ba}_{\mathrm{xs}}$ and excess ${ }^{234} \mathrm{Th}$

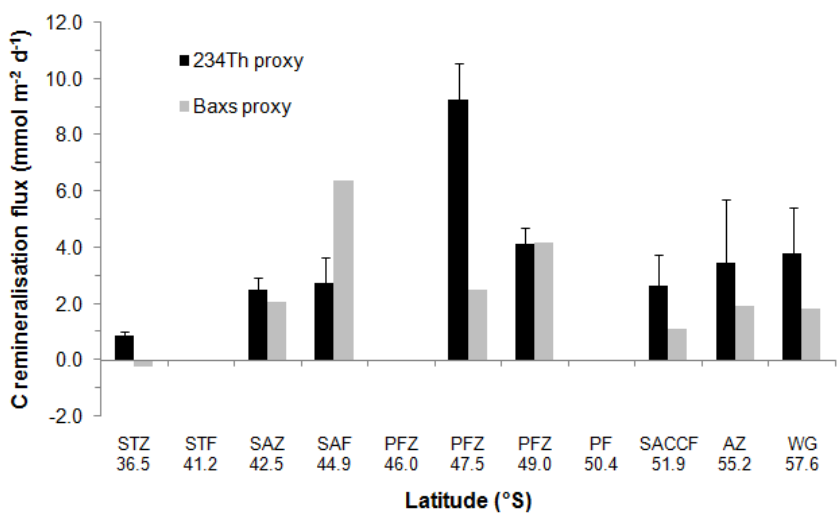

Fig. 10. Remineralisation flux of POC $\left(\mathrm{mmolm}^{-2} \mathrm{~d}^{-1}\right)$ in mesopelagic waters from the ${ }^{234} \mathrm{Th}$ and $\mathrm{Ba}_{\mathrm{x} s}$ proxies.

are of similar magnitude (Figs. 9b and 10). A closer look at the data in Fig. 2 indicates that at some stations maxima of $\mathrm{Ba}_{\mathrm{xs}}$ occur at different depths than ${ }^{234} \mathrm{Th}$ excess. For instance, at $\mathrm{L} 3(\mathrm{SAF}){ }^{234} \mathrm{Th}$ excess is highest around $150 \mathrm{~m}$, whereas $\mathrm{Ba}_{\mathrm{xs}}$ exhibits a sharp peak of $1079 \mathrm{pM}$ at $250 \mathrm{~m}$. In the central PFZ (S3) where remineralisation from ${ }^{234} \mathrm{Th}$ is particularly large, high $\mathrm{Ba}_{\mathrm{xs}}$ concentrations occur between 250 and $500 \mathrm{~m}$, below the maximum of ${ }^{234} \mathrm{Th}$ excess between $120 \mathrm{~m}$ to $400 \mathrm{~m}$. Such differences indicate that the break-up of ${ }^{234} \mathrm{Th}$-bearing particles is not exactly overlapping with the release of $\mathrm{Ba}_{\mathrm{xs}}$ particles from the aggregates and microenvironments in which they originally formed. This likely reflects differences in carrier particle size and compositions. Furthermore the time scales integrated by both proxies may be different: ${ }^{234} \mathrm{Th}$ deficits integrate processes that occurred over a 2 to 3 week period preceding sampling (Buesseler et al., 1992), while the $\mathrm{Ba}_{\mathrm{xs}}$ proxy is much less-time constrained and integrates remineralisation over few days to few weeks (Dehairs et al., 1997; Jacquet et al., 2008b). It should also be kept in mind that both proxies have limitations inherent to the conversion from $\mathrm{Ba}_{\mathrm{xs}}$ or ${ }^{234} \mathrm{Th}$ into carbon fluxes, and a significant part of the discrepancies between the two proxies probably come forth from the several assumptions made to calculate $\mathrm{C}$ fluxes. For $\mathrm{Ba}_{\mathrm{xs}}$ this is mainly based on the use of an empiric algorithm, for ${ }^{234} \mathrm{Th}$, the main uncertainty probably resides in the choice of the $\mathrm{POC} /{ }^{234} \mathrm{Th}_{\mathrm{p}}$ ratio of remineralised material.

Remineralisation fluxes of carbon $\left(\mathrm{C}_{\text {respired }}\right)$ are of the same order of magnitude as the fluxes of POC exported from the surface, reflecting the fact that a large fraction of surface export production is mineralized in the mesopelagic zone. However, some differences exist between the two proxies. Close to the SAF $\left(44.9^{\circ} \mathrm{S}\right), \mathrm{C}_{\text {respired }}$ from $\mathrm{Ba}_{\mathrm{xs}}$ data is $\sim 2$ times larger than excess ${ }^{234} \mathrm{Th}$-based estimates, possibly indicating that some $\mathrm{C}$ remineralisation took place earlier in the season and was not integrated by the excess ${ }^{234} \mathrm{Th}$ approach. 


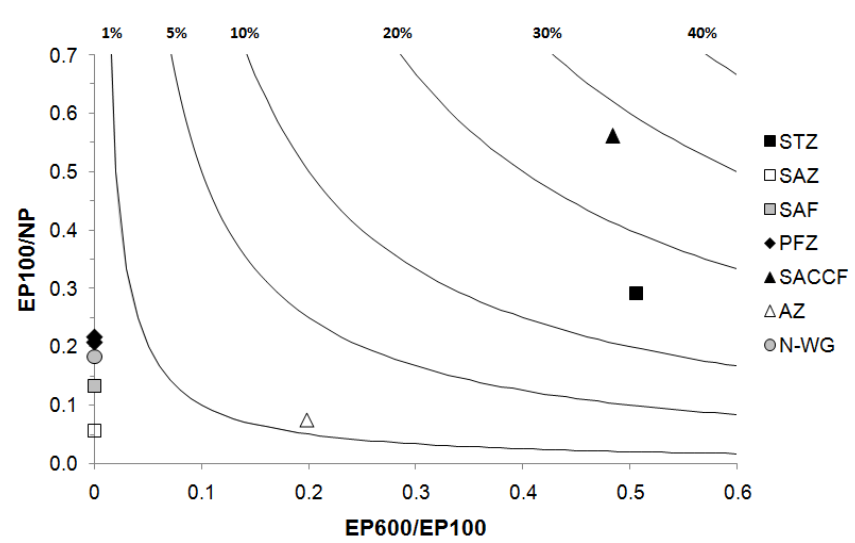

Fig. 11. Ratio of the POC export flux at $600 \mathrm{~m}$ over the export flux at $100 \mathrm{~m}$ (EP600/EP100) versus the ratio of the export flux at $100 \mathrm{~m}$ over new production (EP100/NP). Isolines represent the modelled $1,5,10,20,30$ and $40 \%$ of NP exported to depths $>600 \mathrm{~m}$. Note: $\mathrm{EP} 600=\mathrm{EP} 100-$ Remineralised C flux; EP100 and remineralised C flux estimated using the 234Th approach; negative EP600 fluxes were set to zero. NP from Joubert et al. (2011).

By contrast, in the PFZ ( $\left.47.5^{\circ} \mathrm{S}\right), \mathrm{POC}$ remineralisation from excess ${ }^{234} \mathrm{Th}$ is 5 times higher than $\mathrm{C}_{\text {respired }}$ from $\mathrm{Ba}_{\mathrm{xs}}$. It is possible that in this case we see an effect due to a fragmentation of sinking aggregates as well particle input associated with zooplankton migration and fecal pellet excretion. These would affect the total ${ }^{234} \mathrm{Th}$ distribution and would not necessarily be paralleled by increased bacterial remineralisation of sinking POC, affecting the $\mathrm{Ba}_{\mathrm{xs}}$ content. Overall, results highlight that the PFZ and the SAF are areas of very efficient mesopelagic remineralisation.

Remineralisation rates often exceed export rates from the surface (see Fig. 7b), probably reflecting the fact that the study took place in late summer at a time where primary production is decreasing, i.e., when export was already relatively low. It is possible that mesopelagic remineralisation proceeds on particles which were formed earlier in the season and were associated with larger export fluxes. Such a trend toward higher remineralisation rates during the progress of the growth season is a feature that has been reported before in the Southern Ocean (Cardinal et al., 2005; Jacquet et al., 2011).

\subsection{Bathypelagic POC fluxes}

The fate of surface POC exported to the mesopelagic zone determines longer term sequestration of POC in the deep ocean. We explore the efficiency of POC transfer to depths $>600 \mathrm{~m}$ by calculating the fraction of exportable production (EP) reaching depths $>600 \mathrm{~m}$ (Fig. 11). Therefore we consider the ratio of POC export at $100 \mathrm{~m}$ over new production $\left(\mathrm{EP}_{100} / \mathrm{NP}\right.$; NP data from Joubert et al., 2011) versus the transfer efficiency through the mesopelagic, defined as the ratio of POC flux at $600 \mathrm{~m}$ (i.e., $\mathrm{EP} 600=\mathrm{EP}_{100}$ - remineral- isation flux) relative to the POC flux at $100 \mathrm{~m}\left(\mathrm{EP}_{600} / \mathrm{EP}_{100}\right)$, following Jacquet et al. (2011). Deep-ocean sequestration efficiency appears negligible in the SAZ, PFZ and N-WG, mainly because of a very efficient mesopelagic remineralisation. The AZ exhibits a slightly larger, but still very small sequestration efficiency (close to $1 \%$ ). The STZ and SACCF areas show the highest carbon sequestration efficiencies (close to 15 and $27 \%$, respectively, Fig. 11). Note that for the SACCF area, carbon sequestration is similar (26\%) when fluxes are computed relative to MLD rather than the $100 \mathrm{~m}$ horizon, with $\mathrm{EP}_{\mathrm{ML}} / \mathrm{NP}=0.68$ and $\mathrm{EP}_{600} / \mathrm{EP}_{100}=0.38$.

\section{Conclusions}

In this Southern Ocean study the distribution of short-lived ${ }^{234} \mathrm{Th}$ and biogenic particulate $\mathrm{Ba}\left(\mathrm{Ba}_{\mathrm{xs}}\right)$ are combined to document late summer export of POC from the surface and its fate in the mesopelagic zone.

Steady state modelling of ${ }^{234} \mathrm{Th}$ deficit predicts lowest export production in the STZ and the SAZ where highest levels of biomass are observed. To the south, across the PFZ into the Southern ACC, export production increases progressively, in line with substantial deepening of the surface mixed layer and increasing POC to ${ }^{234} \mathrm{Th}$ ratios of sinking particles related with increasing diatom abundance. In the $\mathrm{AZ}$ and the northern branch of the Weddell Gyre we observed a slight decrease in POC export, though values still exceeded those for the STZ and the SAZ. This could partly result from a greater abundance of large diatoms in sinking material. Non steady state modelling of the ${ }^{234} \mathrm{Th}$ flux allowed constraining export production over a period of 2 to 3 weeks preceding the BGH expedition. For the area between SAZ and SACCF non steady state model calculations revealed significantly lower POC export compared to steady state calculations, suggesting that late summer conditions with low levels of silicate and iron combined with predominance of regenerated production, could be factors limiting export. In contrast, further south in the AZ and the northern Weddell Gyre, both modelling approaches (non steady state and steady state) yield similar POC export values, indicating export production in this low productivity and high nutrient area remained relatively constant over the season. Although ${ }^{234} \mathrm{Th}$-based export flux and new production both increase southward, ${ }^{234} \mathrm{Th}$ based fluxes are consistently lower. Considering that new production represents the "total potentially exportable fraction" of organic $\mathrm{C}$, the discrepancy observed between the two proxies may indicate that surface POC export efficiency is particularly low in late summer.

Below the export zone in the mesopelagic layer, excess ${ }^{234} \mathrm{Th}$ activities as well as accumulation of particulate biogenic Ba provide strong evidence for significant though variable degrees of POC remineralisation. The attenuation of sinking particles appears particularly intense across the ACC, between the STF and the SACCF. While remineralisation in 
the SAZ, the AZ and the N-WG essentially occurs between subsurface and $400 \mathrm{~m}$, it extends much deeper for the region bounded by SAF and PF leading to highest attenuations of export being located there. Although some differences exist between these two independent proxies, excess ${ }^{234} \mathrm{Th}$ and meso- $\mathrm{Ba}_{\mathrm{xs}}$ yield similar estimates of POC remineralisation. When compared to export production we find that remineralisation of POC in the twilight zone is particularly efficient in the studied area thereby impacting on longer term bathypelagic POC sequestration.

\section{Supplementary material related to this article is

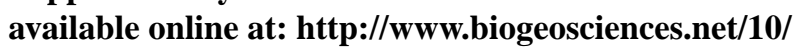 803/2013/bg-10-803-2013-supplement.pdf.}

Acknowledgements. The BONUS-GoodHope cruise is part of the IPY ICED and GEOTRACES programmes. We are grateful to co-chief scientists Sabrina Speich and Marie Boyé, the French Polar Institute, IPEV (Institut Paul Emile Victor) and the captain and crew of $\mathrm{R} / \mathrm{V}$ Marion Dufresne for their assistance during cruise preparation and operations at sea. Constructive comments by Michiel Rutgers van der Loeff and Nicolas Savoye are greatly appreciated and helped improving the manuscript. We are also grateful to Michael Korntheuer for state of the art beta counter maintenance, Jacques Navez, Laurence Monin, and Nouredine Dahkani for helpful laboratory assistance. This work was supported by the Federal Belgian Science Policy Office (BELSPO) under the Science for Sustainable Development (SDD) programme (Integrated Study of Southern Ocean Biogeochemistry and Climate Interaction in the Anthropocene BELCANTO contracts EV/37/7C, EV/03/7A, SD/CA/03A).

Edited by: E. Boss

\section{References}

Arhan, M., Speich, S., Messager, C., Dencausse, G., Fine, R., and Boye, M. : Anticyclonic and cyclonic eddies of subtropical origin in the subantarctic zone south of Africa, J. Geophys. Res., 116, C11004, doi:10.1029/2011JC007140, 2011.

Bowie, A. R., Brian Griffiths, F., Dehairs, F., and Trull, T. W.: Oceanography of the subantarctic and Polar Frontal Zones south of Australia during summer: Setting for the SAZ-Sense study, Deep-Sea Res. Pt. II, 58, 2059-2070, 2011.

Bown, J., Boye, M., Baker, A., Duvieilbourg, E., Lacan, F., Le Moigne, F., Planchon, F., Speich, S., and Nelson, D. M.: The biogeochemical cycle of dissolved cobalt in the Atlantic and the Southern Ocean south off the coast of South Africa, Mar. Chem., 126, 193-206, 2011.

Boyd, P. W.: The role of iron in the biogeochemistry of the Southern Ocean and equatorial Pacific: a comparison of in situ iron enrichments, Deep-Sea Res. Pt. II, 49, 1803-1821, 2002.

Boyd, P. W. and Trull, T. W.: Understanding the export of biogenic particles in oceanic waters: Is there consensus?, Prog. Oceanogr., 72, 276-312, 2007.
Buesseler, K. O.: The decoupling of production and particulate export in the surface ocean, Global Biogeochem. Cy., 12, 297-310, 1998.

Buesseler, K. O., Bacon, M. P., Kirk Cochran, J., and Livingston, H. D.: Carbon and nitrogen export during the JGOFS North Atlantic Bloom experiment estimated from ${ }^{234} \mathrm{Th}:{ }^{238} \mathrm{U}$ disequilibria, Deep-Sea Res. Pt. A, 39, 1115-1137, 1992.

Buesseler, K. O., Ball, L., Andrews, J., Cochran, J. K., Hirschberg, D. J., Bacon, M. P., Fleer, A., and Brzezinski, M.: Upper ocean export of particulate organic carbon and biogenic silica in the Southern Ocean along $170^{\circ}$ W, Deep-Sea Res. Pt. II, 48, 42754297, 2001.

Buesseler, K. O., Barber, R. T., Dickson, M.-L., Hiscock, M. R., Moore, J. K., and Sambrotto, R.: The effect of marginal ice-edge dynamics on production and export in the Southern Ocean along 170 W, Deep-Sea Res. Pt. II, 50, 579-603, 2003.

Buesseler, K., Andrews, J., Pike, S. M., Charette, M. A., Goldson, L. E., Brzezinski, M. A., and Lance, V. P.: Particle export during the Southern Ocean Iron Experiment $\left(\mathrm{SOFe}_{\mathrm{X}}\right)$, Limnol. Oceanogr., 50, 311-327, 2005.

Buesseler, K. O., Benitez-Nelson, C. R., Moran, S. B., Burd, A., Charette, M., Cochran, J. K., Coppola, L., Fisher, N. S., Fowler, S. W., Gardner, W. D., Guo, L. D., Gustafsson, Ö, Lamborg, C., Masque, P., Miquel, J. C., Passow, U., Santschi, P. H., Savoye, N., Stewart, G., and Trull, T: An assessment of particulate organic carbon to Thorium-234 ratios in the ocean and their impact on the application of $234 \mathrm{Th}$ as a POC flux proxy, Mar. Chem., 100, 213-233, 2006.

Buesseler, K. O., Antia, A. N., Min Chen, Fowler, S. W., Gardner, W. D., Gustafsson, O., Harada, K., Michaels, A. F., van der Loeff, M. R., Sarin, M., Steinberg, D. K., and Trull, T.: An assessment of the use of sediment traps for estimating upper ocean particle fluxes., J. Mar. Res., 65, 345-416, 2007.

Buesseler, K. O., Lamborg, C., Cai, P., Escoube, R., Johnson, R., Pike, S., Masque, P., McGillicuddy, D., and Verdeny, E.: Particle fluxes associated with mesoscale eddies in the Sargasso Sea, Deep-Sea Res. Pt. II, 55, 1426-1444, 2008.

Buesseler, K. O., Pike, S., Maiti, K., Lamborg, C. H., Siegel, D. A., and Trull, T. W.: Thorium-234 as a tracer of spatial, temporal and vertical variability in particle flux in the North Pacific, Deep-Sea Res. Pt. I, 56, 1143-1167, 2009.

Cardinal, D., Dehairs, F., Cattaldo, T., and André, L.: Geochemistry of suspended particles in the Subantarctic and Polar Frontal Zones south of Australia: Constraints on export and advection processes, J. Geophys. Res., 106, 31637-31656, doi:10.1029/2000JC000251, 2001.

Cardinal, D., Savoye, N., Trull, T. W., André, L., Kopczynska, E. E., and Dehairs, F.: Variations of carbon remineralisation in the Southern Ocean illustrated by the Baxs proxy, Deep-Sea Res. Pt. I, 52, 355-370, 2005.

Chen, J. H., Lawrence Edwards, R., and Wasserburg, G. J.: 238U,234U and 232Th in seawater, Earth Planet. Sci. Lett., 80, 241-251, 1986.

Chever, F., Bucciarelli, E., Sarthou, G., Speich, S., Arhan, M., Penven, P., and Tagliabue, A.: Physical speciation of iron in the Atlantic sector of the Southern Ocean along a transect from the subtropical domain to the Weddell Sea Gyre, J. Geophys. Res., 115, C10059, doi:10.1029/2009JC005880, 2010. 
Cochran, J. K. and Masqué, P.: Short-lived U/Th series radionuclides in the ocean: tracers for scavenging rates, export fluxes and particle dynamics, Rev. Mineral. Geochem., 52, 461-492, 2003.

Coppola, L., Roy-Barman, M., Mulsow, S., Povinec, P., and Jeandel, C.: Low particulate organic carbon export in the frontal zone of the Southern Ocean (Indian sector) revealed by ${ }^{234} \mathrm{Th}$, Deep-Sea Res. Pt. I, 52, 51-68, 2005.

de Boer, A. M., Watson, A. J., Edwards, N. R., and Oliver, K. I. C.: A multi-variable box model approach to the soft tissue carbon pump, Clim. Past, 6, 827-841, doi:10.5194/cp-6-827-2010, 2010.

Dehairs, F., Chesselet, R., and Jedwab, J.: Discrete suspended particles of barite and the barium cycle in the open ocean, Earth Planet. Sci. Lett., 49, 528-550, 1980.

Dehairs, F., Shopova, D., Ober, S., Veth, C., and Goeyens, L.: Particulate barium stocks and oxygen consumption in the Southern Ocean mesopelagic water column during spring and early summer: relationship with export production, Deep-Sea Res. Pt. II, 44, 497-516, 1997.

Dehairs, F., Jacquet, S., Savoye, N., Van Mooy, B. A. S., Buesseler, K. O., Bishop, J. K. B., Lamborg, C. H., Elskens, M., Baeyens, W., Boyd, P. W., Casciotti, K. L., and Monnin, C.: Barium in twilight zone suspended matter as a potential proxy for particulate organic carbon remineralization: Results for the North Pacific, Deep-Sea Res. Pt. II, 55, 1673-1683, 2008.

Friedrich, J. and Rutgers van der Loeff, M. M.: A two-tracer $\left({ }^{210} \mathrm{Po}-\right.$ ${ }^{234} \mathrm{Th}$ ) approach to distinguish organic carbon and biogenic silica export flux in the Antarctic Circumpolar Current, Deep-Sea Res. Pt. I, 49, 101-120, 2002.

Fripiat, F., Cavagna, A.-J., Dehairs, F., Speich, S., André, L., and Cardinal, D.: Silicon pool dynamics and biogenic silica export in the Southern Ocean inferred from Si-isotopes, Ocean Sci., 7, 533-547, doi:10.5194/os-7-533-2011, 2011.

Ganeshram, R. S., François, R., Commeau, J., and Brown-Leger, S. L.: An experimental investigation of barite formation in seawater, Geochim. Cosmochim. Acta, 67, 2599-2605, 2003.

Gladyshev, S., Arhan, M., Sokov, A., and Speich, S.: A hydrographic section from South Africa to the southern limit of the Antarctic Circumpolar Current at the Greenwich meridian, Deep Sea Res. Pt. I, 55, 1284-1303, 2008.

Gruber, N., Gloor, M., Mikaloff Fletcher, S. E., Doney, S. C., Dutkiewicz, S., Follows, M. J., Gerber, M., Jacobson, A. R., Joos, F., Lindsay, K., Menemenlis, D. Mouchet, A., Müller, S. A., Sarmiento, J. L., and Takahashi, T.: Oceanic sources, sinks, and transport of atmospheric $\mathrm{CO}_{2}$, Global Biogeochem. Cy., 23, GB1005, doi:10.1029/2008GB003349, 2009.

Henson, S. A., Sanders R., Madsen E., Morris P. J., Le Moigne F., and Quartly G. D.: A reduced estimate of the strength of the ocean's biological carbon pump, Geophys. Res. Lett., 38, L04606, doi:10.1029/2011GL046735, 2011.

Jacquet, S. H. M., Dehairs, F., Cardinal, D., Navez, J., and Delille, B.: Barium distribution across the Southern Ocean frontal system in the Crozet-Kerguelen Basin, Mar. Chem., 95, 149-162, 2005.

Jacquet, S. H. M., Dehairs, F., Savoye, N., Obernosterer, I., Christaki, U., Monnin, C., and Cardinal, D.: Mesopelagic organic carbon remineralization in the Kerguelen Plateau region tracked by biogenic particulate Ba, Deep-Sea Res. Pt. II, 55, 868-879, 2008a.
Jacquet, S. H. M., Savoye, N., Dehairs, F., Strass, V. H., and Cardinal, D.: Mesopelagic carbon remineralization during the European Iron Fertilization Experiment, Global Biogeochem. Cy., 22, GB1023, doi:10.1029/2006GB002902, 2008b.

Jacquet, S. H. M., Dehairs, F., Dumont, I., Becquevort, S., Cavagna, A.-J., and Cardinal, D.: Twilight zone organic carbon remineralization in the Polar Front Zone and Subantarctic Zone south of Tasmania, Deep-Sea Res. Pt. II, 58, 2222-2234, 2011.

Joubert, W. R., Thomalla, S. J., Waldron, H. N., Lucas, M. I., Boye, M., Le Moigne, F. A. C., Planchon, F., and Speich, S.: Nitrogen uptake by phytoplankton in the Atlantic sector of the Southern Ocean during late austral summer, Biogeosciences, 8, $2947-$ 2959, doi:10.5194/bg-8-2947-2011, 2011.

Klunder, M. B., Laan, P., Middag, R., De Baar, H. J. W., and Ooijen, J. v.: Dissolved iron in the Southern Ocean (Atlantic sector), Deep-Sea Res. Pt. II, 58, 2678-2694, 2011.

Le Moigne, F. A. C., Boye, M., Masson, A., Corvaisier, R., Grossteffan, E., Guéneugues, A., and Pondaven, P.: Description of the biogeochemical features of the subtropical southeastern Atlantic and the Southern Ocean south of South Africa during the austral summer of the International Polar Year, Biogeosciences, 10, 281-295, doi:10.5194/bg-10-281-2013, 2013.

Maiti, K., Benitez-Nelson, C. R., and Buesseler, K. O.: Insights into particle formation and remineralization using the short-lived radionuclide, Thoruim-234, Geophys. Res. Lett., 37, L15608, doi:10.1029/2010GL044063, 2010.

Martin, J. H., Knauer, G. A., Karl, D. M., and Broenkow, W. W. VERTEX: carbon cycling in the northeast Pacific, Deep-Sea Res. Pt. A, 34, 267-285, 1987.

McNeil, B. I. and Tilbrook, B.: A seasonal carbon budget for the sub-Antarctic Ocean, South of Australia, Mar. Chem., 115, 196210, 2009.

McNeil, B. I., Metzl, N., Key, R. M., Matear, R. J., and Corbiere, A.: An empirical estimate of the Southern Ocean air-sea $\mathrm{CO}_{2}$ flux, Global Biogeochem. Cy., 21, GB3011, doi:10.1029/2007GB002991, 2007.

Metzl, N., Tilbrook, B., and Poisson, A.: The annual $f \mathrm{CO}_{2}$ cycle and the air - sea $\mathrm{CO}_{2}$ flux in the sub-Antarctic Ocean, Tellus B, 51, 849-861, 1999.

Monnin, C. and Cividini, D.: The saturation state of the world's ocean with respect to $(\mathrm{Ba}, \mathrm{Sr}) \mathrm{SO} 4$ solid solutions, Geochim. Cosmochim. Acta, 70, 3290-3298, 2006.

Monnin, C., Jeandel, C., Cattaldo, T., and Dehairs, F.: The marine barite saturation state of the world's oceans, Mar. Chem., 65, 253-261, 1999.

Morris, P. J., Sanders, R., Turnewitsch, R., and Thomalla, S.: ${ }^{234} \mathrm{Th}-$ derived particulate organic carbon export from an island-induced phytoplankton bloom in the Southern Ocean, Deep-Sea Res. Pt. II, 54, 2208-2232, 2007.

Nelson, D. M., Anderson, R. F., Barber, R. T., Brzezinski, M. A., Buesseler, K. O., Chase, Z., Collier, R. W., Dickson, M.-L., François, R., Hiscock, M. R., Honjo, S., Marra, J., Martin, W. R., Sambrotto, R. N., Sayles, F. L., and Sigmon, D. E.: Vertical budgets for organic carbon and biogenic silica in the Pacific sector of the Southern Ocean, 1996-1998, Deep-Sea Res. Pt. II, 49, 1645-1674, 2002.

Owens, S. A., Buesseler, K. O., and Sims, K. W. W.: Re-evaluating the 238U-salinity relationship in seawater: Implications for the ${ }^{238}{ }^{2}{ }^{234}$ Th disequilibrium method, Mar. Chem., 127, 31-39, 
2011.

Pates, J. M. and Muir, G. K. P.: U-salinity relationships in the Mediterranean: Implications for ${ }^{234} \mathrm{Th}:{ }^{238} \mathrm{U}$ particle flux studies, Mar. Chem., 106, 530-545, 2007.

Pike, S. M., Buesseler, K. O., Andrews, J., and Savoye, N.: Quantification of 234Th recovery in small volume sea water samples by inductively coupled plasma-mass spectrometry, J. Radioanal. Nucl. Ch., 263, 355-360, 2005.

Pondaven, P., Ruiz-Pino, D., Fravalo, C., Tréguer, P., and Jeandel, C.: Interannual variability of $\mathrm{Si}$ and $\mathrm{N}$ cycles at the time-series station KERFIX between 1990 and 1995 - a 1-D modelling study, Deep-Sea Res. Pt. I, 47, 223-257, 2000.

Resplandy, L., Martin, A.P., Le Moigne, F., Martin, P., Aquilina, A., Mémery, L., Lévy, M., and Sanders, R.,: How does dynamical spatial variability impact ${ }^{234} \mathrm{Th}$-derived estimates of organic export?, Deep-Sea Res. Pt I., 68, 24-45, 2012.

Rutgers van der Loeff, M. M., Friedrich, J., and Bathmann, U. V.: Carbon export during the Spring Bloom at the Antarctic Polar Front, determined with the natural tracer ${ }^{234} \mathrm{Th}$, Deep-Sea Res. Pt. II, 44, 457-478, 1997.

Rutgers van der Loeff, M. M., Buesseler, K., Bathmann, U., Hense, I., and Andrews, J.: Comparison of carbon and opal export rates between summer and spring bloom periods in the region of the Antarctic Polar Front, SE Atlantic, Deep-Sea Res. Pt. II, 49, 3849-3869, 2002.

Rutgers van der Loeff, M., Cai, P. H., Stimac, I., Bracher, A., Middag, R., Klunder, M. B., and van Heuven, S. M. A. C.: ${ }^{234}$ Th in surface waters: distribution of particle export flux across the Antarctic Circumpolar Current and in the Weddell Sea during the GEOTRACES expedition ZERO and DRAKE, Deep-Sea Res. Pt. II, 58, 2749-2766, 2011.

Sarmiento, J. L., Gruber, N., Brzezinski, M. A., and Dunne, J. P.: High-latitude controls of thermocline nutrients and low latitude biological productivity, Nature, 427, 56-60, 2004.

Savoye, N., Buesseler, K. O., Cardinal, D., and Dehairs, F.: 234Th deficit and excess in the Southern Ocean during spring 2001: Particle export and remineralization, Geophys. Res. Lett., 31, L12301, doi:10.1029/2004GL019744, 2004a.

Savoye, N., Dehairs, F., Elskens, M., Cardinal, D., Kopczyńska, E. E., Trull, T. W., Wright, S., Baeyens, W., and Griffiths, F. B.: Regional variation of spring $\mathrm{N}$-uptake and new production in the Southern Ocean, Geophys. Res. Lett., 31, L03301, doi:10.1029/2003GL018946, 2004b.

Savoye, N., Benitez-Nelson, C., Burd, A. B., Cochran, J. K., Charette, M., Buesseler, K. O., Jackson, G. A., Roy-Barman, M., Schmidt, S., and Elskens, M.: ${ }^{234}$ Th sorption and export models in the water column: a review, Mar. Chem., 100, 234-249, 2006.

Savoye, N., Trull, T. W., Jacquet, S. H. M., Navez, J., and Dehairs, F.: ${ }^{234}$ Th-based export fluxes during a natural iron fertilization experiment in the Southern Ocean (KEOPS), Deep-Sea Res. Pt. II, 55, 841-855, 2008.
Shopova, D., Dehairs, F., and Baeyens, W.: A simple model of biogeochemical element distribution in the oceanic water column, J. Marine Syst., 6, 331-344, 1995.

Sigman, D. M. and Boyle, E. A.: Glacial/interglacial variations in atmospheric carbon dioxide., Nature, 407, 859-869, 2000.

Sternberg, E., Jeandel, C., Robin, E., and Souhaut, M.: Seasonal cycle of suspended barite in the mediterranean sea, Geochim. Cosmochim. Acta, 72, 4020-4034, 2008.

Takahashi, T., Sutherland, S.C., Sweeney, C., Poisson, A., Metzl, N., Tilbrook, B., Bates, N., Wanninkhof, R., Feely, R. A., Sabine, C., Olafsson, J., and Nojiri, Y.: : Global sea-air $\mathrm{CO}_{2}$ flux based on climatological surface ocean $p \mathrm{CO}_{2}$, and seasonal biological and temperature effects, Deep-Sea Res. Pt. II, 49, 1601-1622, 2002.

Takahashi, T., Sutherland, S. C., Wanninkhof, R., Sweeney, C., Feely, R. A., Chipman, D. W., Hales, B., Friederich, G., Chavez, F., Sabine, C., Watson, A., Bakker, D. C. E., Schuster, U., Metzl, N., Yoshikawa-Inoue, H., Ishii, M., Midorikawa, T., Nojiri, Y., Körtzinger, A., Steinhoff, T., Hoppema, M., Olafsson, J., Arnarson, T. S., Tilbrook, B., Johannessen, T., Olsen, A., Bellerby, R., Wong, C. S., Delille, B., Bates, N. R., and de Baar, H. J. W.: Climatological mean and decadal change in surface ocean $p \mathrm{CO}_{2}$, and net sea-air $\mathrm{CO}_{2}$ flux over the global oceans, Deep-Sea Res. Pt. II, 56, 554-577, 2009.

Taylor, S. R. and McLennan, S. M.: The Continental Crust: its Composition and Evolution, Blackwell Scientific Publications, Melbourne, Australia, 312 pp., 1985.

Trull, T. W., Bray, S. G., Manganini, S. J., Honjo, S., and François, R.: Moored sediment trap measurements of carbon export in the Subantarctic and Polar Frontal Zones of the Southern Ocean, south of Australia, J. Geophys. Res., 106, 31489-31509, doi:10.1029/2000JC000308, 2001.

Trull, T. W., Bray, S. G., Buesseler, K. O., Lamborg, C. H., Manganini, S., Moy, C., and Valdes, J.: In situ measurement of mesopelagic particle sinking rates and the control of carbon transfer to the ocean interior during the Vertical Flux in the Global Ocean (VERTIGO) voyages in the North Pacific, DeepSea Res. Pt. II, 55, 1684-1695, 2008.

Usbeck, R., Rutgers van der Loeff, M., Hoppema, M., and Schlitzer, R.: Shallow remineralization in the Weddell Gyre, Geochem. Geophys. Geosyst., 3, 1008, doi:10.1029/2001GC000182, 2002.

Waples, J. T., Benitez-Nelson, C., Savoye, N., Rutgers van der Loeff, M., Baskaran, M., and Örjan, G.: An introduction to the application and future use of ${ }^{234} \mathrm{Th}$ in aquatic systems, Mar. Chem., 100, 166-189, 2006. 